\title{
WITNESSING THE GENETIC SELF: HOW NON-SPECIALISTS USE REVEAL VIDEOS TO APPROACH GENETICS AND RACE THROUGH DIRECT-TO-CONSUMER GENETIC ANCESTRY TESTING
}

\author{
by \\ Megan Berry \\ Bachelor of Arts, Mount Royal University, 2015 \\ A major research paper \\ presented to Ryerson University and York University \\ in partial fulfilment of the \\ requirements for the degree of \\ Master of Arts \\ in the program of \\ Communication and Culture
}

Toronto, Ontario, Canada, 2018

(C) Megan Berry, 2018 


\section{Author's Declaration}

I hereby declare that I am the sole author of this MRP. This is a true copy of the MRP, including any required final revisions.

I authorize Ryerson University to lend this MRP to other institutions or individuals for the purpose of scholarly research.

I further authorize Ryerson University to reproduce this MRP by photocopying or by other

means, in total or in part, at the request of other institutions or individuals for the purpose of scholarly research.

I understand that my MRP may be made electronically available to the public. 


\title{
Witnessing the Genetic Self: How Non-Specialists Use Reveal Videos to Approach Genetics and Race Through Direct-To-Consumer Genetic Ancestry Testing
}

\author{
Megan Berry \\ Master of Arts, Communication and Culture \\ Ryerson University and York University, 2018
}

\begin{abstract}
This paper investigates the interpretation and expression at work when those without a higher education in genetics take a direct-to-consumer (DTC) genetic ancestry test (i.e. AncestryDNA) and then communicate this experience through online video on YouTube, most commonly through the Reveal genre of videos. Through non-random quota sampling a diverse corpus for analysis was created and then analyzed through the lenses of critical race theory, intersectionality, and María Lugones's concepts of transparency and thickness, with focusing guidance from Gubium and Holstein's narrative components to uncover how the test-takers approached genetics and race. The variations in how individuals approach their DTC genetic ancestry test results and communicate them through the videos, touching on topics such as race, family, self-identity, and stories, were discovered to work well alongside Roth and Ivemark's recently presented genetic options theory.
\end{abstract}




\section{Acknowledgements}

I would like to thank my master's research paper advisor Dr. Anne MacLennan of the Department of Communication Studies at York University. She swooped in when I was awash with concerns, providing excellent guidance on how to go about the challenge of researching and writing an MRP, pushing for necessary restructuring to help make this paper more readable.

I would also like to thank the many people who helped make this paper comprehensible, including my second reader Dr. Jan Hadlaw of the Department of Design Studies at York University, and Ryerson University's Writing and Graduate Student Support teams led by Dr. Natalya Androsova, who pushed the improvement of my writing overall and provided an invaluable regular writing group during which I completed significant chunks of this paper.

Finally, I wish to thank all those who helped with the research, including my undergraduate professors from Mount Royal University's journalism department, Dr. Amanda Williams and Dr. Janice Paskey, who taught me the basics of academic research and how to organize it before even getting to graduate school, the staff of Ryerson University's Library and Archives and Facilities Management and Development for providing and maintaining a library collection and facilities that got me through the deepest research stages, Dr. Carmen Schifellite of the Department of Sociology at Ryerson for alerting me to some key texts, Dr. Colleen Derkatch of the Department of English at Ryerson for showing me authors who were invaluable in the early stages of my paper, and Dr. Monique Tschofen of the Department of English at Ryerson for being amongst the first to enthusiastically support my interest in studying genetics science and exploring STS, thus giving me the courage to proceed with this research. 


\section{Table of Contents}

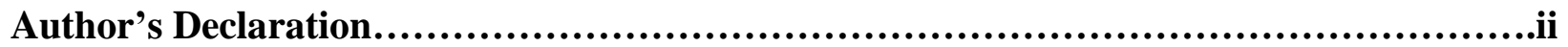

Abstract.............................................................................................iii

Acknowledgements...........................................................................

Introduction and Background................................................................1

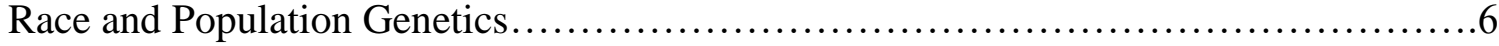

Genetic Genealogy ..................................................... 16

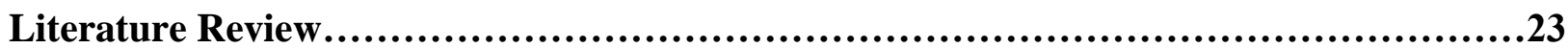

Critical Race Theory and Intersectionality ....................................... 26

Curdling, Multiplicity and Fragmentation, and Transparency and Thickness.............30

How CRT, Intersectionality, and Curdling are Used by Others...................... 33

Sara Díaz................................................................ 33

Amina Mama........................................................... 35

Erving Goffman............................................................ 37

Methods.........................................................................................39

Gubrium and Holstein......................................................... 43

Developmental Stages.............................................. 44

Pattern Alternation and Pattern Elasticity..................................44

Contradictory Themes............................................... 45

Sharing Stories and Creating Linkages................................... 45

Substantive Monitoring................................................. 46

Narrative Ownership.................................................46

Analysis.......................................................................................48

Gubrium and Holstein ..................................................... 50

Developmental Stages............................................... 50

Pattern Alternation and Pattern Elasticity..................................51

Contradictory Themes.............................................. 53

Sharing Stories and Creating Linkages....................................55

Substantive Monitoring...............................................55

Narrative Ownership................................................57

Discussion...............................................................................59

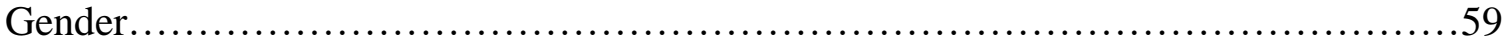

Genetic Options Theory and Identity Multiplicities..............................60

Conclusion.................................................................................64

References................................................................................66 


\section{Introduction and Background}

In 2017, the industry of direct-to-consumer (DTC) genetic testing boomed. Customers more than doubled, resulting in over 12 million people having submitted their saliva or cheek swab sample to companies such as Ancestry DNA, 23andMe, or Promethease and the expectation that the DTC genetic testing industry's market would be worth 340 million USD by 2022 (Regalado, 2018; Williams, 2017). This DTC genetic testing encompasses the phenomenon of an individual submitting their genetics, via a cheek swab or saliva sample, to a company for sequencing and testing. It can result in everything from determining one's genetic ancestry or genetic health risks to simply producing artwork using the autoradiograph imagery produced through the genetic sequencing process, as done by DNA11.

DTC genetic ancestry testing has received significant attention, catalysing many news articles of confusion, surprise, and alarm as people parse through the results they receive after undergoing DTC genetic ancestry testing, some uncovering previously unknown family members, finding family members they had been searching for, or uncovering long buried family secrets (Bevar, 2018; Chung, Glanz, \& Adhopia, 2018; Copeland, 2017; Fetters, 2018; Kolata, 2017; Yong, 2017). Often, these articles have equated ancestry to race while a batch of articles have risen in response, drawing from older articles explaining that genetic ancestry is not race and that in fact race is not a scientifically valid concept (Angier, 2000; Edmonds, 2018; Kolbert, 2018; Lewontin, 2006; Worrall, 2017). Some of these articles have profiled white supremacists disappointed over the discovery of their genetic ancestry, which may show some non-European genetic ancestry, or even more specifically, non-Western European genetic ancestry, throwing their prejudiced beliefs into a tailspin while they struggle to reconcile the genetic ancestry with 
their beliefs about race, society, and ancestry (Boodman, 2017; Reeve, 2016; Zhang, 2016; Zhang, 2017). Again, race is conflated with genes.

Presumably, this conflation and the association of genetic ancestry with race and family is partly why the popularity of DTC genetic testing has exploded. The tests converge on concepts many people hold close: their families, their identities, and their beliefs about and understanding of society and race. It is for this reason that examining what the test-takers are saying about DTC genetic testing is important.

The Reveal is a narrative tool used to centre the reactions of those who have something important to them revealed or unveiled to them, such as when home decorating television shows "reveal" the re-decorated home to the home-owners. The focus of the Reveal is on how those people react to what is revealed to them. Popular across popular culture, showing up as part of multiple television genres and online communities, it is reasonable to assume that the Reveal in DTC genetic testing would be able to illuminate how people are interacting with and responding to DTC genetic ancestry testing. The Reveal in DTC testing was pioneered in DTC genetic ancestry testing by the company African Ancestry when LeVar Burton received his genetic ancestry results live in 2003 (Nelson, 2016, p. 97). Since then, the Reveal has remained an important feature of both genetic and traditional genealogy television, with the show's host communicating the results to the participant, who must then perform their reaction, be it shock, joy, or disappointment. The Reveal also occurs in other media, such as online through YouTube videos and posts on social media (Chow-White et al., 2018; Harris, Wyatt, \& Kelly, 2013; Harris, Kelly, \& Wyatt, 2014; Harris, Kelly, \& Wyatt, 2016; Mittos, Blackburn, \& des Cristofaro, 2018; Nelson, 2016). It requires the audience to take note of the Reveal participant's experiences and may create a "political occasion" wherein the audience is required to reckon 
with the "historical dynamics" of varying family trees exposed through genealogy or genetics (Nelson, 2016, p. 95). Accordingly, the Reveal videos produced by DTC genetic ancestry testing customers that are uploaded online for public viewing are important to examine because they speak to how the customer and their communities approach genetics, race, and family.

Harris, Kelly, and Wyatt $(2014 ; 2016)$ focused both on the Reveal and on associated videos in their analysis of the videos customers of 23andMe posted on YouTube about their experiences with 23andMe. Harris, Kelly, and Wyatt specifically focused on those videos in which people reacted to their genetic health test results, rather than ancestry, using a language around these amateur videographers as "patients-in-waiting" creating their own "autobiologies" (2014, p. $73 ; 2016$, p. 50$)$. With autobiologies defined as texts that engage with one's biochemical body, and as a version of what Nayar calls an autobiogenography, which is simply "the discovery of the self's origins in genetic data," we can assert that not only are Harris, Kelly and Wyatt's studied 23andMe customers autobiologists and autobiogenographers but perhaps those engaging with their genetic ancestry are as well (Nayar, 2016; Nayar, 2017, p. 217).

In their study of YouTube autobiologies, Harris, Kelly, and Wyatt assert that such autobiologies are playful narratives. Previous work establishes that narratives and stories are endemic to YouTube (particularly by Couldry, 2008; Pace, 2008; Kavoori, 2015, but also seen in Burgess \& Green, 2009; Lange, 2008; Strangelove, 2010; Vonderau, 2016), but these specific autobiologies analysed by Harris, Kelly and Wyatt are playful because those learning of their genetic health risks are not currently ill and thus do not have to confront such risks immediately. They engage with the findings in casual settings such as bedrooms and backyards, and they flit from finding to finding as "wayfarers," pausing on findings that are personally intriguing either because of a lack of knowledge or because they knew that they would have such a genetic health 
risk (Harris, Kelly, \& Wyatt, 2014, p. 73-74). The autobiologies the customers construct through video engagement with the 23 andMe genetic test findings are woven into their existing biographies and added to their self-knowledge, creating a more comprehensive bank of data about themselves (Harris, Kelly, \& Wyatt, 2016, p. 51).

The focus on the personal and the importance of one's own biography makes the uploading of such videos to YouTube rather obvious. Founded in 2005 before being bought by Google, the Google subsidiary YouTube focuses on "giv[ing] everyone a voice and show[ing] them the world", based on four freedoms: freedom of expression, freedom of information, freedom of opportunity, and freedom to belong (YouTube, 2018). YouTube endeavours not only to give everyone a platform from which to speak but to "build community through our stories," implying that not only are biographies welcomed and indeed expected, but that YouTube itself is a part of the community and not simply the host or the platform upon which a community is created (YouTube, 2018).

Strangelove's (2010) research on the earlier years of YouTube (now 13 years old in 2018) shows that it is a community but not one divorced from the communities offline or found on other sites. Through hyperlinks, reproduction of cultural norms, engaging with or even reproducing existing cultural materials such as presentations and music that may also be found on other websites, YouTube's commenting and messaging functionality, and the creation of YouTube-based brands and businesses by YouTube uploaders (aka YouTubers), the YouTube community and its sub-communities regularly engage with other online communities and offline communities. This creates a complex web of interactions that involves: businesses of a variety of sizes that may be in partnerships with YouTube or collaborating on projects through YouTube Red, YouTube Music or YouTube Gaming; individuals who may or may not post videos or 
comments and may simply exist as a part of a video's view counts or a source of hyperlinks to the video on other websites, and; advertisers who use Google's and YouTube's data to target their advertisements to viewers either in the form of banners or short videos played before or during YouTube videos (YouTube Red, 2018).

Resultingly, the stories YouTubers tell through the videos they upload as vlogs, episodes of original scripted shows, educational works, news stories, or others, are likely engaging with not only the values and norms present in YouTube and the community they're a part of on YouTube, but also the values and norms present in the communities they're a part of offline and in other online spaces. And they are telling stories, as Pace (2008) presented in a marketing analysis of YouTube and Kavoori (2015) argued in his content analysis of YouTube and its participatory culture.

Kavoori (2015) worked to extend from the work of earlier scholars such as Strangelove (2010) and Burgess and Green (2009), which focused on more quantitative broad strokes rather than a content analysis of YouTube. While Kavoori recognized that performing a content analysis of YouTube as a whole was nigh-impossible, a fact also recognized by Burgess and Green (2009), Kavoori did focus on the most commonly occurring videos on YouTube and conducted a broad content analysis of those videos, identifying seven video types: "The Phenom, The Short, The Mirror, The Morph, The Witness, The Word and The Experiment" (2015, p. 8). The Reveal falls into some combination of The Mirror and The Witness types. It is part of The Mirror because depending on how the Reveal functions within the uploader's YouTube channel, it may be an addition to an existing vlog or other continual video series, functioning as a kind of special episode that records the self"s biology as a "public memory of personal...continuity" (Kavoori, 2015, p. 11). In this sense, The Mirror type uses YouTube's 
extended status as an archive to its advantage (Burgess \& Green, 2009). The Reveal is also part of The Witness because, again partly depending on how the Reveal functions within the uploader's YouTube channel, the video may function as a kind of journalistic report on the effectiveness or the experience of going through DTC genetic testing in the same vein as the multitude of mainstream news articles do on exactly that topic (Kavoori, 2015).

Studies of YouTube would benefit further from engagement with the racial and cultural backgrounds of those creating and uploading videos. As Nakamura (2008) points out, studies of race and digital culture, particularly the digital divide, that only measure access or consumption without measuring production are going to miss an important component of the entire digital environment. Who is likely to produce videos on their experiences with DTC genetic ancestry testing? To make such a hypothesis we would need to consider the demographic breakdowns of those creating and uploading videos to YouTube, particularly vloggers, along with the demographic breakdown of those using DTC genetic ancestry testing. Are these people YouTube celebrities or stars? Do they engage with both their genetic ancestry and their nationality, as some YouTube celebrities do when they exaggerate national stereotypes for comedic effect (Smith, 2014)? And do they adhere to YouTube's former statement that it's used to 'Broadcast Yourself' or do they loop in more with the community focus YouTube asserts today? These questions are beyond the scope of this paper but will be kept in mind for framing purposes due to the importance of race and culture in genetic ancestry.

\section{Race and Population Genetics}

Why focus on race and culture when studying DTC genetic ancestry? Because users of genetic ancestry tests associate genetic ancestry with race, as shown in Roth and Ivemark's (2018) qualitative study of DTC genetic ancestry testing users and Mittos, Blackburn, and de 
Cristofaro's (2018) research on Twitter users' reactions to their DTC genetic ancestry test results. Users of DTC genetic ancestry tests also associate genetic ancestry with family, as shown in Chow-White et al.'s (2018) similar study, which is, in turn, closely associated with culture. Furthermore, the social effects of race that turn it into a large component of many people's identities, and people's impressions of other's identities, makes race important when considering genealogy and family, both of which are closely associated with genetic ancestry. The cultural, social, economic, and political effects of race have made people's connections to their ancestors either incredibly strong (through oral or physical documentation, such as photographs, records of settlements or unions, or stories and other oral assertions) or incredibly weak (through their ancestors being forbidden from having physical documentation or unable to pass on oral documentation, often due to racial or other discriminations, either institutionalized or incidental). Either may provide motivation for pursuing identification of one's genetic ancestry.

The cited association of race with genetic ancestry is not unreasonable given that the social effects of racial taxonomy are long-standing, far-reaching, and generally defined based on that which is relatively easy to see (such as skin colour) and understand when compared to seeing and understanding the migrations and interactions of people thousands of years ago that contributed to our genetic status today and resulted in today's genetic ancestry test results (McKinley, 2008). Additionally, genetic ancestry as proof of 'race' is used as part of social and legal systems, such as the blood quantum system, which historically and today uses blood interchangeably with genes as either a symbolic or actual tool in the United States to determine the tribal status of Native Americans ${ }^{1}$ (TallBear, 2013). Related, DTC genetic ancestry tests

\footnotetext{
1 "Native Americans" is used here both because it is used in TallBear's book and to distinguish Indigenous peoples and their socio-political statuses currently in the United States from the Indigenous peoples and their socio-political statuses currently in Canada, who are often referred to as a group as First Nations, Métis, and Inuit, or as the Indigenous Peoples of Canada when more specific designations (such as Nēhiyaw) would be less useful. I will use
} 
themselves are constructed in a way that associates one's results with a specific geographic population, and in turn with that population's majority or Indigenous race. This appears to be due to the cultural prominence of race as a tool of organization, a prominence which neither the scientists developing or the customers using genetic ancestry tests are likely to escape.

Georges-Louis Leclerc, a French naturalist, is credited as being the first to propose a racial taxonomy however, nine years later in 1758 "Swedish botanist, zoologist and physician Carolus Linneaus" defined in Systema Naturae four racial groups and assigned them characteristics built from the broad racist socio-political beliefs of the day (Lee, 2015, p. 146). Those four groups were “Americanus reubescus, Europaeus albu, Asiaticus luridus, and Afer niger" roughly equivalent to Native Americans, Europeans, Asians, and Africans (Lee, 2015, p. 146). The fact that genetic ancestry is determined based on people whose ancestry can be reliably traced back to a specific area of the planet, makes it easy to link the genetic ancestry testing process with the historical association of race with geography. With race associated with geography due to Linneaus's and other's work existing alongside the association of genetics with geography due to the importance of geography in migration and reproduction across populations, and collaborating with the association of today's political and territorial borders with geography and therefore in turn race and genetics as well, an environment is created where geography,

\footnotetext{
similar reasoning when using the terms "black" or "African American" or "Time" or "white" or "UkrainianCanadian" or "Ukrainian" except for when referring to a specific individual, at which point I will use the individual's preferred terminology. If the region of the speaker or the culture associated with a particular term is important, that will be highlighted either by identifying that region or culture by capitalizing a term (i.e. "black" to refer to a general black population when the self-identification of being racially black is more important in that situation than any specific cultural or regional markers; "Black" to refer to a generalized global Black population that identifies both racially and culturally, and in some cases ethnically, with the Black diaspora; Black American to refer to the Black American population that does not specifically identify with any diasporic community but rather with Black American culture and ethnicity; African American to refer to the American community of the African diaspora; or Guinean American to refer to the American community of the Guinean diaspora).
} 
genetics, race, and politics are apparently automatically interrelated and nigh-inseparable. It is this environment in which the scientists pinpointing genetic ancestry work.

Genetic ancestry is determined by looking at the parts of a person's genome that signal genetic variation, called single-nucleotide polymorphisms, or SNPs. Y-SNPs can track a person's paternal ancestry using Y-chromosome DNA and similarly mtDNA SNPs track a person's maternal ancestry using mitochondrial DNA (Kayser \& de Knijff, 2011). Y and mtDNA SNPs can then be divided into haplogroups identifying a paternal or maternal ancestor respectively. These haplogroups are in effect major genetic families that trace back to a single source of the $\mathrm{Y}$ or mtDNA SNPs, a single individual, such as the mtDNA haplogroup L in Africa, P and Q in Oceania, or V in Europe and the Middle East (Jackson \& McDonald, 2008; Kayser \& de Knijff, 2011). At DTC genetic testing companies, genetic ancestry is identified using such a method of tracking SNPs, but differ with regard to what pools of data and algorithms they use to target and identify different SNPs. One company may have a data pool comprised of dominantly Europeandescended individuals and for those with a Y chromosome use an algorithm that targets, for example, Y-SNPs 1, 4, and 16, while another company may have a data pool comprised of dominantly Asian-descended individuals and use an algorithm that targets Y-SNPs 1, 3, and 6. Due to the different data pools and algorithms the results of those who have some European genetic ancestry will be more comprehensive at the first company, whereas those with some Asian genetic ancestry will get results more comprehensive at the second company, and if either individual switched companies their results would look slightly different due to the fact that their DNA is being compared to different data pools comprised of different DNA and use different algorithms to target different SNPs. 
A common refrain when scientists are asked about the accuracy of the tests used by DTC genetic ancestry companies is that the tests aren't profoundly accurate in the way that people expect them to be (Brown, 2018). This is because genetic ancestry and your reaction to it is perception, time, and location dependent. It depends on what you perceive to be your root ancestry—is that a century ago, five centuries ago, or a few thousand years ago; the time when the genetics your genes are being compared to are gathered — are they present-day people's genetics or are they the genetics of people or a single person who lived thousands of years ago and how are their genes identified or sequenced; and both where in the world those genes are gathered from and how you refer to those areas - they could be referred to by contemporary nation-state names, by the names of geographical areas, or even by migration patterns. Depending on what SNPs are targeted and what the company's data pool is, you may get different results at different companies. Moreover, genetic ancestry becomes less accurate the more specific you get. While it is somewhat useful for identifying continental variations-if you are willing to consider a continent a large landmass where multiple groups intermingled and mixed over thousands of years, occasionally also mingling and mixing with populations from other continents throughout time- -it is much less useful for asserting anything smaller, such as country-level ancestry. This is partly because migration between countries on a single continent is relatively easy when compared to migration across continents separated by vast distances or geographical features such as oceans or mountains, and therefore it would have been much easier for your ancestors to interact with those physically closer to them, causing a greater occurrence of genetic overlap (Kayser \& de Knijff, 2011; TallBear, 2013).

Furthermore, the countries some companies use today to identify ancestry simply did not exist tens, hundreds, or thousands of years ago. The application of countries to genetic ancestral 
origins is simply a way to categorize test results so that people can grasp the approximate area their ancestors were possibly from. From this the customers are given the opportunity to identify with that area's culture. This intention is shown in advertisements by companies such as Ancestry DNA, which has used ads showing customers changing cultural clothing, food, or music after finding out, for example, that they were not genetically German but in fact genetically Scottish (Ancestry, 2016). Additionally, if you are getting tested alongside your genetic parents or siblings and find that your sibling has Central Asian genetic ancestry you do not have, do not be surprised. During reproduction you received half of your DNA from your genetic mother and half from your genetic father, that DNA was random and then further randomly combined and recombined to create you (Helix, 2017; Risch \& Lange, 1979; Visscher et al., 2006). It was a random roll of the genetic dice as to whether you, your sibling, both, or neither would inherit the Central Asian ancestry found in your shared genetic father. Likewise, for the populations prior to you, so while there may seem to be a common genetic marker amongst Population A, a person may not inherit that common genetic marker despite knowing that they are part of Population A. Genetic ancestry results are, overall, probabilistic, and based on the work of population genetics, which is meant to be used for entire groups not specific individuals (Roth \& Ivemark, 2018). Moreover, those groups are defined based on the perspectives of the scientists involved, which may not incorporate the complex migratory, cultural, political, and social histories of the peoples being studied (Nash, 2007; Reardon, 2011; Roth \& Ivemark, 2018).

Population genetics comes from studies used to assign groups to specific geographic areas based on their genetics and has been occurring most notably since the time of the Human Genome Project (HGP). The Human Genome Diversity Project (HGDP, not associated with 
HGP) and the International HapMap Project (HapMap) used population genetics around the same time as HGP to create maps and records of the planet's genetic ancestry (Chow-White, 2008; Lee, 2015; Nash, 2007; Reardon, 2011). HGP determined that all humans are "99.9\% the same at the genomic level" while HGDP, with the ultimate determination that race is indeed a social construct rather than biological fact, and HapMap worked from the assumption that there are genetic human differences and with the right tools and expertise those differences can be found and compared (Chow-White, 2008, p. 1181; Long \& Kittles, 2003; Reardon, 2011; Templeton, 1999).

Reardon's (2011) critique of HGDP and HapMap points out that the scientists working on the projects worked from the assumption that they were the experts able to not only identify differences between humans but able to determine which groups were permitted recognition in the first place to test for differences, in effect determining which bodies were valuable and which populations to be morally committed to. "By placing the power to determine group membership in the hands of experts - such as population geneticists - the Diversity Project, Native attorneys contended, threatened to encroach upon" the rights of Indigenous communities to "determine their own membership" and in doing so the HGDP and later HapMap failed to acknowledge or consider the ability of their projects to affect the definitions of the actual groups being studied and the concept of a group itself (Reardon, 2011, p. 226). Additionally, the use of "precise" descriptive names such as Zurich, Switzerland versus Swiss in Zurich, Switzerland focus on using geographical labels only meaningful for people or populations who do not have or have not moved much (Reardon, 2011, p. 229). Related, in using continental designations that pertain to commonly used racial terms, such as African, Asian, or European for some genetic populations while switching to subcontinental designations such as Scandinavian or Kenyan, which can 
easily relate to commonly used ethnic terms, the interpretation of results from genetic ancestry tests can be impacted profoundly (Roth \& Ivemark, 2018). Roth and Ivemark point out that "Americans may be more likely to interpret a migration line ending in central Europe as German but a line ending in central Africa as African" and this may be because of their own geographical or historical understandings, how the results are communicated to them (ex. as French and German vs. South Central African), or a combination of both (2018, p. 153).

Like HGDP, the National Geographic's Genographic Project perceives mixing and mingling as the enemy, as a challenge to be overcome when trying to determine the genetic differences of people originating from different areas of the world and their historical migration patterns (Nash, 2007). Akin to HGDP, the Genographic Project's "stated focus... is on human migration and genetic interconnection, but nevertheless ignores the[ir] construction of 'genetically and culturally isolated' indigenous peoples [and] ignores the continuous history of 'mixing' that has shaped even those groups named as 'isolates of historic interest'”' (Nash, 2007, p. 81). In attempting to identify and isolate the genetic differences within humans, the Genographic Project, HGDP, and HapMap engage in what Nash calls a "primitivist fetishization of purity" that ignores the possibility of historical migration while operating from an assumption of biological difference within humanity that is disturbingly reminiscent of the assigning of racial difference. How these projects define a population is important. Do they do it based on "patterns of genetic variation" while accounting for the migration and mixing that has occurred over the course of human history, or do they define a population based on existing "culturally defined human groups" and compare the genetics of those groups with other "culturally defined human groups" (Nash, 2007, p. 80-81)? Whatever route they take, population geneticists often wind up either inadvertently or purposefully charting human difference racially, and these 
findings are then used beyond the study to argue that it supports the idea of biological races (Nash, 2007). This is done without consideration of the geneticists' knowledge that racial labels are simply "convenient labels for what are effectively statistically descriptive boundaries within gradients of genetic variation that are themselves subject to the nature of the sampling and numbers of [genetic] markers examined" (Nash, 2007, p. 84).

The practice of formally assigning racial difference started by Leclerc and Linnaeus has continued widely and resulted in various consequences, including granting a false impression of scientific validity towards the inhumane treatment and exploitation of racialized people in a white dominant system. This helped lead to not only the ravages of the Middle Passage, but to studies of racialized groups such as those carried out on Sara Baartman, or the experimentations on black women carried out by J. Marion Sims; the development of eugenics logic and methodologies, which placed those who were not succeeding according to the measures of the white authority as failures due to their biology and specifically their genetics, and resulted in eugenics programs such as those overseen by the Alberta Eugenics Board or most widely by Nazi Germany; efforts to decrease birth rates among poor and often racialized women initiated by Margaret Sanger and other early birth control advocates, which was often motivated by eugenics logic or used eugenics methods such as sterilization; the development of contraceptive technology, which used poor women of colour from Puerto Rico as research subjects and consent methods that would never pass review today; the mid- $20^{\text {th }}$ century Tuskegee syphilis study, which exploited poor black men in the American south; and the 1989 genetic study of the Havasupai tribe in Arizona (Bates \& Harris, 2004; Díaz, 2012; Eig, 2014; Fausto-Sterling, 2002; Kapsalis, 2002; Lee, 2015; McLaren, 1990). 
The legacies of this exploitation can carry across generations, as Bates and Harris (2004) show in their studies on how non-specialists talk about and understand genetic technologies of the early to mid-2000s. In one study on advertisements of pharmacogenomics products that targeted consumers based on their race, the studied consumers reacted critically, resisting the conflation of pharmacogenomics with race and often wanting more information, only accepting the advertised claim based on a specific reason built from critical thought (Bates, Poirot, Harris, Condit, \& Achter, 2004). This finding is visible across other studies, with non-specialists being largely suspicious and critical of assertions of race being related to health and medicine, though this perspective can shift based on individual experiences, such as if an individual participates in a clinical study that is divided based on race (Bates, Lynch, Bevan, \& Condit, 2005; Bevan et al., 2003; Condit \& Bates, 2005; Lynch \& Dubriwny, 2006). In similar studies, this suspicion and critical thought is applied further to an individual's willingness to engage with genetic studies, with members of populations that have been exploited in biomedical studies historically questioning who has "the ability to research whom and how," while being more reluctant to participate or at least more aware of the possibility of racialized exploitation, such as through referencing past exploitations like the Tuskegee study (Bates \& Harris, 2004; Bates et al., 2005; TallBear, 2013, p. 116).

This legacy is interesting when applied specifically to DTC genetic health testing companies. Unfortunately, there is little research done specifically on DTC genetic health testing companies and the approaches of different racial populations to it. This is partly a methodological problem, as most studies that do look at DTC genetic testing companies focus on the people who have already used their services and do not look at those people who have not used them. The research that does exist on people who use DTC genetic health testing companies 
does not bother to identify racial differences or cultural differences and instead focuses on differences based on health status and genetic health testing. This reluctance to identify such racial or cultural differences could be due to the historical exploitation of racialized groups and a wish to not repeat such exploitation, or it could be due to the framework such articles are working in, which often involves the authors reiterating the assertion that race has no genetic basic and therefore is or should be irrelevant to their study. When the studies are focusing on identifying people's reactions to their test results, their propensity to make lifestyle changes, and similar, it seems to be an oversight to not consider cultural differences, or racial differences (which originate from socio-cultural factors brought on by living in a racialized society).

Moreover, research focused on users of DTC genetic health testing tends to get large numbers of white participants and few others (such as in Carere et al., 2014; Harris, Kelly, \& Wyatt, 2016; Lee, 2013a; Lee, 2013b), therefore there are large swaths of populations missing. Often this lack of non-white participants is explained to be because these populations are not using the test but why is rarely questioned. It may be because of a lack of interest, a concern over how the data is used and how it's stored, or perhaps a lack of finances or unwillingness to put finances towards the test. Finances are important because users also tend to be at least middle class and educated, but if the users are only one or neither they may be involved in the testing for another reason, such as having encountered a health scare or experiencing a lack of knowledge about their genetic health due to, for example, adoption (Baptista et al., 2016; Crouch, Yu, Shaker, \& Tabor, 2015; Strong et al., 2017).

\section{Genetic Genealogy}

Sociologist Alondra Nelson charted the work of Rick A. Kittles and his company African Ancestry for over a decade, getting involved in not only genetic ancestry testing communities but 
genealogy communities and communities that combine both. African Ancestry was one of the first DTC genetic ancestry testing companies to be established, alongside "Family Tree DNA (2000-); Gene Tree (2001-2013) and Relative Genetics (2001-2008), both owned by Sorenson Genomics, and DNAPrint Genomics (2002-2009)" (Nelson, 2016, p. 66). African Ancestry was created by Rick Kittles and Gina Paige for the African-American market (Nelson, 2016). ${ }^{2}$ The African-American market was focused on for a few reasons: (1) the then recent African Burial Ground project in Manhattan that Kittles participated in, during which skeletons of AfricanAmericans were discovered and the discussion of how to scientifically study the remains involved an argument for less of a focus on race and more of a focus on who the people were, what they did, and what happened to them; (2) the recent sequencing of the human genome through HGP and development of ancestry-focused genetic studies such as the Genographic Project, HapMap, and HGDP made the project of finding one's genetic roots enter the cultural milieu; (3) the unique barriers confronting African-Americans who wanted to know more about their ancestry and themselves but descended from people who suffered through the Middle Passage and whose existence was recorded, if at all, under the names of white slave-owners, were less prominently addressed if addressed at all; and (4) there was, and remains, a lack of DTC genetic ancestry testing companies that have a comprehensive database suitable for charting African rather than European ancestry (Chow-White, 2008; Lee, 2015; Nash, 2007; Nelson, 2008; Nelson, 2013; Nelson, 2014; Nelson, 2016).

\footnotetext{
${ }^{2}$ In this case, "African-American" refers to Americans with a genetic connection to the African continent, even if the individuals do not culturally connect with the African diaspora. These individuals may identify as racially black or another race, mixed race, biracial, or through another racial identification not listed here. This terminology is used because it is used by Nelson, Kittles and Paige in this context. The term "Black American" will be used interchangeably.
} 
Nelson (2016) explains that engagement with companies such as African Ancestry by Black Americans occurred as a development of the genealogical fad that spread across the country due to the publication and broadcasting of Alex Haley's Roots: The Saga of an American Family, a book and later television miniseries where Haley apparently tracked his own genetic ancestry through America and back to the African continent. Haley's book and later television miniseries was later revealed to be based on fiction rather than fact, but was a rousing success in the late 1970s due to its ability to reckon with a brutal history (Nelson, 2016, p. 70). As Nelson espouses, "in place of a presidential apology for slavery, or a national discussion on racism, or the promise of reparations, we had Roots" (2016, p. 70). Roots' success was capitalized on by the production of kits for genealogical charting, which helped bolster the popularity of genealogical research (Nelson, 2016).

As genetic ancestry tests became more affordable they became a part of the genealogical charting process as an addition to more traditional genealogical research or, in some cases, the starting point for genealogical research. However, it wasn't only for genealogical purposes that genetic ancestry tests became popular for Black Americans. It was also to fulfill a "desire to feel complete" and to find "a stronger sense of belonging in the United States and on the continent of Africa" while "reckon[ing] with the history of slavery" (Nelson, 2016, p. 22). Parallel with this utility was the ability to use such tests to foster reconciliation or recognition. For example, Las Abuelas de Plaza de Mayo use genetic ancestry tests to connect the victims of the Argentinian Dirty War to one another, allowing families torn apart to be reunited through mtDNA tests of grandparents and grandchildren (Nelson, 2016). In the 1989 case of the Havasupai tribe in Arizona, DNA samples were taken from the tribe by Arizona State University ostensibly to study diabetes, but instead the samples were used to study schizophrenia, migration, and inbreeding 
(Lee, 2015). The Havasupai took the ASU researchers and Arizona Board of Regents to court and came out with $\$ 700,000$ compensation, the return of the DNA samples, and funding for a school and clinic (Havasupai Tribe v. Arizona Board of Regents, 2008; Harmon, 2010).

In the early 2000s, before the DTC genetic ancestry testing boom, the prospect of charging people for access to their genetic ancestry seemed to some to be immoral, particularly when those wanting access to their genetic ancestry were victims of slavery (Nelson, 2016). Michael Blakey and Fatimah Jackson, scientists from the African Burial Ground project, suggested that the genetic ancestry tracing methods they used during the project and the reference DNA database they were developing be made available to the public for free (Nelson, 2016). Over a decade later, despite the methodological improvements that Blakey was hoping for to make free genetic ancestry information a reality, Kittles's idea of creating a company that would charge people to receive information on their genetic ancestry is now commonplace and a free option is rarely discussed.

Genealogical work thus becomes a type of labour that can cost money if incorporating genetic ancestry testing. This unpaid, or more accurately, labour you pay to perform, is dominantly performed by women. Nelson notes this is consistent with research on "the practice of maintaining family ties"; a form of gendered labour mostly undertaken by women that involves facilitating communication between family members, providing aid to family members, or in this case, widening the family and providing knowledge of the family $(2016, \mathrm{p}$. 71). While there is some literature on the gender of those undertaking genealogical projects, there is little literature commenting on the gender of those taking genetic ancestry tests, which appears to be an oversight and perhaps a useful avenue for further research (Harris, Kelly, \& Wyatt, 2014; Lee, 2013a; Lee, 2013b; TallBear, 2013). 
Genetic ancestry tests are used today for various reasons. Beyond the personal and private, which may be basic curiosity, seeking a personal understanding of historical dynamics, or engaging with a diaspora they suspect they could be a part of, people also engage with genetic ancestry tests for socio-political reasons (Nelson, 2016). Nelson outlines the reasons for Las Abuelas using genetic ancestry testing to be both personal—rebuilding one's disarticulated family—and political—addressing the legacy of the war—and similarly outlines reasons for individuals such as Deadria Farmer-Paellmann to use genetic ancestry. Using the cases of reparations granted to Japanese Americans interned by the federal government during World War Two and reparations for slave laborers forced by the Nazi government to work for various manufacturers, Farmer-Paellmann and her fellow reparations activists sought to not only put pressure on companies that benefitted from the slave trade but to use genetic ancestry testing to confirm their own status as descendants of slaves (Nelson, 2016, p. 129-130). After appeals the case was ultimately thrown out of court due to an "issue of jurisdiction," the statute of limitations that Farmer-Paellmann hoped to circumvent by "invoking human rights norms," and an inability to establish a definitive and uninterrupted ancestral line from an individual plaintiff to a former slave along with a definitive line of capital "gained from an accused corporation to expropriated laborers and their offspring" (Nelson, 2016, p. 135-136).

A similar socio-political function for genetic ancestry tests is invoked by multiple Indigenous communities. For the Uros, an Indigenous community living in Peru around and on artificially constructed islands in Lake Titicaca, genetic ancestry testing granted them the ability to affirm their ethnic identity as Uros (Kent, 2012). Due to their status in Peru where their ability to present themselves as Uros assisted with tourism and other economic ventures, a confirmation of themselves as Uros would only help (Kent, 2012). However, after receiving some genetic 
confirmation that only some of them carried some Uros ancestry, the pre-existing socio-cultural divide amongst the population and between their own community and others in Peru continued to exist based on how they engaged with and lived alongside or upon the islands and lake (Kent, 2012). The socio-cultural system was, in the end, more powerful than the genetic test results. Politically, in the United States, genetic ancestry testing can be used to affirm or adhere to the blood quantum system. The blood quantum system is used to identify Native Americans based on their DNA, which in this case is conflated with blood (TallBear, 2013). It is through this system that Native Americans are recognized, politically and legally, within the United States. This system can be used to assert rights to territory, control tribal membership, and gain or lose access to services. It creates a culture wherein if through the blood quantum system you are recognized as Native American and wish your child to also be recognized as such, you must perform mental math every single time you meet a prospective reproductive partner to ensure that the combination of your own Native American DNA and your partner's Native American DNA results in a child who will also be recognized under the blood quantum system as Native American.

That said, biological association with an Indigenous community does not guarantee membership. Often, it is a combination of biology and sociality focused around one's knowledge of the claimed Indigenous community's culture, and the inquiry of "You know your tribe, but does your tribe know you?" (Sturm, 2010, p. 14). Without the social dimension the political significance of identification with an Indigenous community is rendered moot and the person identifying as part of that community will often become a descendant of that community rather than a politically recognized current member. 
As seen by the Uros and Native Americans, Indigenous communities tend not to engage with genetic ancestry testing purely for the knowledge gained from it, if they engage at all, instead if they do engage they will likely do so because of the test's possible political value (Kent, 2012). 


\section{Literature Review}

As briefly outlined above, race and genetics have a storied history. Research coming out today often focuses on DTC genetic ancestry testing and the races of the customers, along with their understanding of race and their propensity to embrace or reject racial identities they perceive as revealed through the results of their genetic ancestry tests (see Chow-White et al., 2018; Mittos, Blackburn, \& de Cristofaro, 2018; Roth \& Ivemark, 2018). This research builds on previous research about race and genetics, reaching as far back as the first works of eugenicists or racial taxonomy of Linnaeus and co. As such eugenicist work is a clear example of poorly performed science, however, most research builds off the work of rhetoricians such as Celeste Condit, who spent the late 1990s and early to mid-2000s researching the rhetoric of race and genetics in the middle of the booming interest in genetics caused by the Human Genome Project (for more on the rhetoric of race and genetics see Bates \& Harris, 2004; Bates et al., 2004; Bates et al., 2005; Caulfield \& Harry, 2008; Condit, 1999; Condit \& Bates, 2005; Condit et al., 2001; Condit et al., 2004; Lynch et al., 2008; Lynch \& Dubriwny, 2006; Nash, 2004; Ryall, 2008; Saukko, 2017). Often, this research found that consumers of genetic technologies or advertisements were critically consuming the technology or advertisements and questioned any relationships asserted to be between race or genetics, yet they found themselves in a "doublebind" by identifying with an ethnic group or race and facing a genetic product or finding said to be particularly important or useful for a certain ethnic group or race (Bates et al., 2004; Bates et al., 2005; Condit, 1999; Condit et al., 2001; Lynch \& Dubriwny, 2006; Nash, 2004). This

product or finding was, of course, important to them as something that could be used to improve their health or understanding of their own biology, yet they simultaneously had to recognize the inaccuracy of the geneticized race or ethnicity presented to them, resulting in the aforementioned 
“double-bind" (Lynch \& Dubriwny, 2006). More recent research has offered alternatives to the common conception of race (Phelan, Link, Zelner, \& Yang, 2014), critiqued existing research on race and genetics (Frank, 2015), focused specifically on investigating DTC genetic testing or similar initiatives such as biobanks (Lee, 2013; Lee, 2015; Mittos, Blackburn, \& De Cristofaro, 2018; Rachul, Ouellette, \& Caulfield, 2011; Roth \& Ivemark, 2018), or have done more traditional rhetorical and sociological research focused on uncovering various racial beliefs in the genomic age, what they are, and how they form (Byrd \& Ray, 2015; Donovan, 2017; Gillborn, 2016; Phelan, Link, \& Feldman, 2013).

In a study of tweets about genetic testing, Mittos, Blackburn, and De Cristofaro found "several instances" of racist tweets when tweeters complained that their genetic ancestry test results showed they had a multiracial background — which the authors categorised as "multicultural/multi-ethnic" while the tweeters used the terminology of "race" $(2018$, p. 10). Other tweeters expressed their genetic ancestry test results in a humorous way, reportedly mostly about being white - "Like, rice on a paper plate with a glass of milk in a snowstorm, white" (Mittos, Blackburn, \& De Cristofaro, 2018, p. 11). Likewise, Roth and Ivemark (2018) examined through qualitative interviews how recipients of DTC genetic ancestry tests reacted to their results and changed or did not change their identities based on those results. From this research, sociological work on genetic determinism and social identity theory, and partly influenced by Nelson's (2008) work on genealogical aspirations, Roth and Ivemark developed genetic options theory, which includes two components: (1) the "identity aspirations" of the individual engaging in the DTC genetic ancestry testing, which guides them towards which identities they wish to claim, and; (2) their "social appraisals," which is an estimation of how other people will react to their identity claims (2018, p. 152). Roth and Ivemark found in interviewing the users of DTC genetic 
ancestry tests that white users often use any non-white components of their test results to take on a non-white identity component to address their perception "of whiteness as boring or plain," thus addressing the first principle of genetic options theory but still having to contend with the second principle, perhaps by expressing this new identity component "selectively" (2018, p. 153). In contrast, non-white users value the new ancestral components their test results reveal but do not often take on new identity components, thus they approach the two principles of the genetic options theory with less of an inclination towards changing their identity (Roth \& Ivemark, 2018). This adoption and acceptance of new identities or identity components is on a continuum, ranging from full and complete acceptance, to partial acceptance, to complete rejection of the genetic ancestry test results (Roth \& Ivemark, 2018).

Related, in a study of the terminology used in genetic research to describe different populations, tracing the terminology across a peer-reviewed article to a press release to a newspaper article, the authors found that racial terminology was used across the different genres in a variety of ways (Rachul, Ouellette, \& Caulfield, 2011). For example, some examined peerreviewed articles used particular racial terms and then justified the use of those terms, but the press releases about those articles did not include the justification and the newspaper articles would either use those terms provided or use their own, so while the racial terminology may have traveled the entire route the justification or explanation would not because the writers did not treat racial terms as specialized terminology, despite other specialized terms being explained by those same newspaper articles and press releases (Rachul, Ouellete, \& Caulfield, 2011). As a result, how people react to and use or do not use race or racial terminology in their interpretation of genetics, specifically genetic ancestry tests and their results, is currently difficult to predict. 


\section{Critical Race Theory and Intersectionality}

Borne from anti-black racism, critical race theory (CRT) takes the position that racial groups and associations with racial groups come from "history, custom, and legalized injustice" (Zack, 2010, p. 878). Due to its origins within anti-black racism, CRT is also strongly associated with the work of black feminists such as Kimberlé Crenshaw and Patricia Hill Collins. Crenshaw (1989) introduced the concept of intersectionality, highlighting how social, cultural, and political structures affect the features of individuals and groups, making those of a certain gender and/or race, for example, varied in their visibility and vulnerability within and around those structures. These considerations were originally intended to facilitate and encourage a more comprehensive understanding of the lives of racialized women, specifically black women, while encouraging people to ask what questions they are missing and should be asking, and how and why the structures and systems around us work in the way they do and for whom they do or do not work for. This concept of intersectionality has expanded further with Crenshaw to encompass class, sexuality, age, and even nationality, enabling people to gain a comprehensive understanding of their own and others' lived experiences with varying social, cultural, and political structures.

Collins (2000) built off Crenshaw's concept of intersectionality and focused specifically on the experiences and thoughts of black women when writing Black Feminist Thought, with the goal of giving ink to the traditionally ignored or denigrated thoughts and perspectives of black women, both scholars and not. Collins took the approach that in analysing traditionally maligned people's "ideas and actions... as subjects" from the perspective that such "ideas and actions" are "statement[s] of philosophy," both the researcher and analysed subject can be scholar and activist (2000, p. 17). This approach is encouraging, as it suggests that when people produce something on a topic they do not have an advanced education in (such as ancestral genetics) there remains a 
profound value to the product. Despite a lack of technical or professional understanding of the topic, the product will still be demonstrative of the producers' own philosophical perspectives and will permit them to be scholars and/or activists unbeholden to the oft-rigid expectations of traditional institutions. The works of such voices are thus valuable precisely because they are the works of those who are not considered a part of those institutions and/or they do not adhere to the traditional expectations of institutions.

In Black Feminist Thought, Collins (2000) took significant care to explain how the experiences of Black women, and specifically Black American women (or, U.S. Black women, or African-American women, as Collins refers to them) inform their approach to work, selfidentity, family, sex, love, and the overall development of Black feminist thought. Centrally, she points out that the linking of power relations and the intersectionality of Black women's experiences deeply affects every aspect of the lives of Black women. The importance of this fact is not erased by the fact that the concept of "Black Woman" is socially constructed, just as any other racial identity or any assertion of the gender binary (Collins, 2000, p. 166). In short, the socially constructed nature of the concepts we discuss does not negate their importance.

In outlining the effect that being a Black woman has on one's experiences, Collins (2000) crucially addresses the importance of family through chapters such as "Mammies, Matriarchs, and Other Controlling Images," "Black Women's Love Relationships," and "Black Women and Motherhood." In the first chapter, "Mammies, Matriarchs, and Other Controlling Images," Collins explains how belonging gains significance when the images of Black women adhere to specific stereotypes that attempt to emphasize a lack of belonging of Black womanhood, while explaining through bell hooks how one (in this case a Black woman) is defined and named only by virtue of her relationship to the one in dominant power (a White man, a White woman, or a 
Black man, depending on the context) (2000, p. 71). In the chapter "Black Women's Love Relationships" Collins discusses the occurrence of "biracial or mixed-race children" in Black American society, running through the complex dynamics that rise when such children are born to White mothers and Black American fathers (2000, p. 165). The Black woman relatives or friends wind up being brought in to "accept and love" the children of these White women and their Black male relatives or friends, thus becoming the "Black mothers that these children do not have," while the children provide a reminder of the rejection of the "Black men...[who] leav[e] so many [Black women] without partners" (Collins, 2000, p. 165). Thus, Collins continues to explain the challenges associated with Black women finding, entering, and maintaining relationships with Black men.

This chapter leads into the following, "Black Women and Motherhood" where Collins (2000) explains the numerous rates of Black women caring for other children in a kind of informal community childcare system, with neighbours caring for other neighbours' children, and "becoming a biological mother... [being] seen as a significant step toward womanhood" (p. 196). The centrality then of the "superstrong Black mother" extends past the images introduced in "Mammies, Matriarchs, and Other Controlling Images," into the love relationships of Black women, and finally to the Black mother either mothering her own children (biological or not) or another person's children (Collins, 2000, p. 174). The family and the centrality of the mother within it is integral for understanding the family dynamics of Black Americans and therefore we can ask whether these family dynamics and the importance of the mother is duplicated in the genetic ancestral family. While it would be nigh-impossible to confirm such dynamics in families from thousands of years ago, we can ask if these dynamics are found when people, in this case Black Americans, engage with their genetic ancestral family. Based on Collins's (2000) 
work then, the importance of the mother to parenthood and shepherding the next generation of Black Americans into adulthood cannot be overstated when preserving or seeking understanding of the Black American family's genetic or genealogical lineage. Furthermore, this importance of the mother and the extending family dynamics must be brought into bear when understanding how that preservation or seeking impacts the family's and the individuals' sense of self and family. ${ }^{3}$

Related, Collins points out that "all women are assigned the duty of reproducing the national group's population, and of passing on a national culture while simultaneously being inscribed with that same national culture," so women must have babies and teach them the national culture, but this duty is given differing importance depending on what each woman's race and class is (2000, p. 231). Working-class women of either race (Collins refers only to White women and Black women) are discouraged from having babies, but working-class Black women are discouraged more because working-class White women can have babies and then pass them off for adoption by middle-class White families (Collins, 2000, p. 231). Black women cannot do this and preserve the look of the White middle-class family. Contrastingly, middleclass White women are encouraged to have children and improve their fertility through the latest in reproductive technologies, while middle-class Black women are simply discouraged, as all Black women are, from having children (Collins, 2000, p. 231). Undocumented women, particularly undocumented women of colour, are not only discouraged from having children, but the very idea of them having children is a threat to the nation-state (Collins, 2000, p. 231). The continuing ancestral lines of Black women and undocumented women of colour are thus threats to the nation-state. When Black women and undocumented women of colour have children who

\footnotetext{
${ }^{3}$ For a discussion on adoptive parents and family dynamics, see Crouch, Yu, Shanker \& Tabor, 2015.
} 
then have children themselves, and so on and so forth, only to then seek to find and understand their genetic ancestry and thus illuminate even more genetic relations, they are pushing back against a racist system that discourages them and their ancestors and descendants from even existing. The very existence of their genetic children and genetic parents pushes against the nation-state's discouragement of them having children. Similarly, a White woman's refusal to have genetic children pushes against the nation-state's encouragement for her to have children. This preoccupation with genetic family, and the expectation that babies are adopted by parents of the same racial background but a higher class (thus, working-class White women have children adopted by middle-class White families), reinforces racialized assumptions about biology and a refusal to recognize multi- or bi-racial people, while degrading the importance of adoptive, foster, or other non-biological families in favour of biological families reproducing for the nation-state. With this background in mind then, it could appear to be downright audacious for a Black woman to seek out understanding of her ancestry, thus reaffirming that, despite being discouraged from having children, her ancestors did in fact have children, who then had children themselves, and so on and so forth, leading to not only herself but others. Reproduction, and therefore genetic ancestry, are deeply impacted by race and class and play a very important role in policy and politics. Therefore, the considerations of CRT, and specifically Black feminist thought, should be incorporated into any study looking at genetics labs or companies.

\section{Curdling, Multiplicity and Fragmentation, and Transparency and Thickness}

Further work associated with CRT is found in María Lugones' (1994) development of the concepts of curdling, multiplicity, and fragmentation. These concepts focus specifically on the impact of expectations and self-adjustment caused by one's race and gender, but can be expanded to include one's class, sexuality, and nationality. 
Lugones introduces the concept of curdling by explaining the making of mayonnaise. She explains that after dropping yolk into a bowl, adding water and oil, and stirring, if one measurement is off the mixture may separate or curdle. This curdled emulsion implies separation of the ingredients but Lugones argues that this is inaccurate; in fact, the water and oil largely separate but the rest of the ingredients coalesce toward oil or water in "different degrees of coalescence," thus creating "yolky oil and oily yolk" (Lugones, 1994, p. 459). Curdling is thus both separation — a form of purity—and coalescence—a form of impurity (Lugones, 1994). This purity/impurity curdling relationship is present in human relations as well. In a similar vein to Crenshaw's work on intersectionality, Lugones (1994) points out that sociality is complex, and individuals contain multiplicities. When the individual subject grasps this multiplicity in both themselves and the world they can both separate and coalesce. They can curdle.

Genetic ancestry similarly contains multitudes combined in different ways. Genetic ancestry is a yolky and oily experiment that forces individuals and even their families to face multiple variations of themselves: themselves before the test, themselves during the test, and themselves after the test. They must decide which parts of the test they want to take with them and which parts they do not want to take with them, and then decide if any of it is useful for themselves and their lives. Simultaneously, test-takers must contend with the racial implications of the test, because while they may not apply race to their genetic ancestry, others will often apply it to them. Resultingly, the claim of purity in the social world, that is, something which is viewed as the basis for everything else and is often white, cis-gendered, male, heterosexual, ablebodied, neurotypical and middle-class, is put under threat. Lugones (1994) points out that this body is a multiplicity, yet it is socially not identified as such and is instead identified as a form of purity. Anything diverging from this pure body's measurements is thus a multiplicity and the 
pure body remains a singular. Genetic ancestry threatens this claim of purity. Genetic ancestry throws into relief the multiplicity of bodies once seen as pure. Genetic ancestry marks those once pure bodies as multiplicities, making them noteworthy and impure like the bodies they were once placed against to be called "pure."

Multiplicity may help lead to what Lugones calls fragmentation. Fragmentation happens when a person's perspectives, values, and interests are not identical to those of the wider group (Lugones, 1994). The wider group that has a set of shared perspectives, values, and interests includes: transparent individuals, who perceive their perspectives, values, and interests as those of the group, and those perspectives, values, and interests as becoming the dominant ones of the group; and thick individuals, who perceive their perspectives, values, and interests as not those of the group, therefore they are the Others of the group, marginalized by the group (Lugones, 1994, p. 474). Thick individuals are fragmented and erased, transparent individuals are not. Fragmentation occurs when social groups are split based on purity and homogeneity of perspectives, values, and interests adhering to the needs of transparent individuals (Lugones, 1994). The same transparent individuals in that group may then become thick and fragmented when they enter various other groups also built on purity and homogeneity, because even transparent individuals who deny their multiplicity and are told to deny their multiplicity are in fact in possession of multiplicity (Lugones, 1994, p. 475). Everyone contains curdling multiplicities and transparent individuals only exist as transparent individuals by faking purity and unity, while thick individuals can often not fake such purity and unity because their bodies are already marked as multiplicities due to their status as not-male, not-white, not-heterosexual, not-middle or upper class, or not American (Díaz, 2012, p. 20-21). Therefore, thick individuals must choose to either exist within their multiplicities and not bother trying to imitate the vantage 
point that comes with fragmenting oneself to appear pure, or they must fragment themselves and try to imitate the vantage point that comes with such fragmentation (Díaz, 2012). There is no middle ground.

When receiving their genetic results, the test-takers may encounter some surprises and learn that they are in possession of multiplicities they had previously either been ignorant to or attempted to ignore. Whether those multiplicities are then embraced or rejected is another question entirely but could lead to the fragmentation described above. Due to such fragmentation, Lugones argues for groups made up of "nonfragmented persons ... that reveal the enmeshing of race, gender, culture, class, and other differences that affect and constitute the identity of the group's members" (1994, p. 475).

\section{How CRT, Intersectionality, and Curdling are Used by Others}

Sara Díaz. In her dissertation, Sara Díaz (2012) wrote a feminista science studies analysis of three women of colour scientists—-Roger Arliner Young (1899-1964), Chien-Shiung Wu (1912-1997), and Sor Juana Inés de la Cruz (1648-1695)—using María Lugones’s theory of curdling, multiplicity, separation, fragmentation, transparency, and thickness. Díaz introduces her analysis by explaining why she opted to only focus on three subjects, pointing out that quantitative statistical methods are used to study averages and her subjects are not a part of the average population or a large population, either as women of colour scientists or scientists in general, and therefore to use quantitative methods would be largely useless $(2012$, p. 7).

Moreover, she points out with help from Collins that the critiques of quantitative methodologies come from critiques of positivism and objectivism, which discounts the importance of observations from someone who is in an "other" or "outsider" within an institution due to the observations being both (a) assumed to be or actually the result of not objective tests but 
subjective perspectives, and (b) coming from an individual or population that is not statistically significant in the studied institution (Díaz, 2012, p. 8-9). Both irritations result in a cycle of reaffirming only the statistically significant experiences of the entire institution (in academic institutions this means largely white males, and largely the middle to upper-classes) and degrading any that fall outside the narrow window of statistically significant. If you only study the statistically significant you'll miss outliers, which is often the point, but when someone does wish to study the outliers they are then cautioned against it because there's little research emphasizing whether the outliers have any importance or not.

Díaz goes deep into Lugones's concepts of curdling, multiplicity, fragmentation, transparency, and thickness, applying them to Young and $\mathrm{Wu}$ primarily, concluding that Young, a Black American woman, rejected fragmentation and chose to embrace her multiplicity, while Wu, a Chinese woman who immigrated to America, used curdling and fragmentation. Díaz (2012) used a collaboration of Lugones's work and Crenshaw's work to discuss how in rejecting fragmentation and embracing her multiplicity Young had limited access to academic institutions and the elite due to being a black woman from a lower class than her fellow academics while eugenics was widespread and racial taxonomy labeled black people, particularly black women, as the lowest of the low. Assuming awareness, either conscious or unconscious, amongst DTC genetic customers of the existing heavily racialized social, cultural, and political world, it may be expected that customers will choose to embrace and reject varying portions of their results due to their associations with the results. Young, in choosing to reject fragmentation of her multiplicities, embraced her status as a Black American woman academic from a lower socioeconomic class and this affected not only her academic career but her personal life and her activist work as well. Similar effects were found for Wu. 
Appearing pure and conforming was useful for $\mathrm{Wu}$ as her work was shaking the foundations of physics in the 1930s (Díaz, 2012, p. $106 \&$ 136). Therefore, Wu used fragmentation to assert her place in science and defend her objectivity, which was questioned due to her being a woman, and used curdling in "embodying cultural, racial, and gender differences in the laboratory," which enabled Wu to simultaneously challenge the fundamentals of physics and adhere to the expectations and values of the physics field (Díaz, 2012, p. 153). Unlike Young, Wu came from a well-off family in China, though had little contact for an extended period of time due to international politics, and was entering physics at a time when physics was opening to traditionally rejected populations due to the pressures of war, so the financial and field concerns for $\mathrm{Wu}$ were not as extreme as they could have been, although she had the issue of little familial contact to contend with (Díaz, 2012). Looked at through Crenshaw's intersectionality, despite significant barriers presented by her race and gender, Wu was afforded some significant advantages by her class and the socio-political environment in which she did some of her work.

Díaz rounds out her analysis using Lugones's framework by pointing out that unity or purity is an "imperialist impulse" that refuses to engage with the multiplicity of people's experiences (2012, p. 219). Rather than viewing the lack of a central unified narrative as a disaster, Díaz argues that the multiplicity of narratives found amongst women of colour should be interpreted as a strength (2012, p. 218-219).

Amina Mama. While she did not use Collins's work specifically to guide her, due to working before Collins's books were published, in the 1990s sociologist Amina Mama (1995) nevertheless utilized elements of the historical and broader black feminist thought explored by Collins. For her book Beyond the Masks: Race, Gender, and Identity Mama (1995) explored the 
Black African and Black Caribbean diasporas in Britain. Focusing specifically on African British and Caribbean British women, Mama took a case study approach through the methodology of "open-ended exploratory discussions" conducted in the individuals' homes or communities and rising from social practices that already occurred and involved Mama and her participants (1995, p. $72 \& 73)$.

Mama's research was ultimately about securing knowledge, not only for her work and herself, but for her research participants as well, to facilitate a kind of "consciousness-raising" of the intersectionality of their experiences and the possible and proven causes of those experiences, and to act as a witness and record of the experiences of her research participants, all of which were impacted by their identities as black women in Britain with a connection to the African or Caribbean diasporas (1995, p. 72). Therefore, Mama addresses the concerns espoused by Collins (2000) to look at and preserve the experiences of black women in all their variations without reproducing the patriarchal, racist, and colonialist research done in the past on black populations, and black women specifically.

Methodologically, Mama used black feminist thought, anti-black racism, and CRT. Regarding her findings however, Mama was able to expand on each facet. She began her work from the position that subjectivity is central and continued with that position as her research progressed, concluding that identity is dynamic and the various present associations with race are a product of history, which includes customs and culture, as well as injustices both institutionalized and not (Mama, 1995). Dynamic identity proved to be central to Mama's research. Connections to ancestral communities in Africa or the Caribbean, either existing or desired, sometimes both alongside a sense of "rootlessness," permeated the discussions Mama engaged in (Mama, 1995, p. 117). Mama also works alongside Lugones's later work on 
multiplicity, pointing out that many of her research participants use multiple identities, enabling them to adopt, for example, a Rastafarian culture to build cultural roots while adjusting the presentation of their self (Rastafarian with a desire to move to Africa) in appearance, language, and more, if they want to get a job in Britain (Mama, 1995, p. 119-121). Mama (1995) emphasizes the constant renegotiation that occurs as the participants rework their identities as they become exposed to various cultures and people, but that there is a constant expectation of racialized people to reaffirm their racial identity because it is presented as so central to the person's identity and yet simultaneously unstable. Mama theorizes that this is due to racialized people — she speaks specifically of black people — in Britain living in a majority white society and thus constantly being reminded of their status as Other, making them constantly conscious of "being black" (1995, p. 134). Contrastingly, black people in Africa do not consciously spend time "being black" because to do so would be "redundant" in areas where the majority population is black (Mama, 1995, p. 134). Therefore, we can see that a relationship of race to geography does exist, but only socially.

\section{Erving Goffman}

In 1959, Goffman explained how people express themselves in public. Key to his work is the idea that the people on the front of the stage will adopt a specific persona or project a certain identity towards others. In turn, the audience will attempt to support the adoption of that persona or identity, such as by ignoring when an error is being made, or by playing along with a story.

This was challenged by Bullingham and Vasconcelos (2013), who found that when online, people would try to recreate their offline self, often by highlighting certain aspects of their offline self. Additional minor alterations or embellishments may occur in the creation of this online avatar, or the offline self may even be split apart so that different facets of themselves 
may be found in different online spaces, but Goffman's idea of an adoption of a new persona rarely occurred. It can be assumed that this would carry over from their work on Second Life and written blogs onto YouTube vlogs, where the use of an avatar is a less-accessible option and instead the vlogger is presenting their actual physical face on video towards their viewers. This becomes multiplied in complexity when you bring in genetic ancestry, which may present the impression of total accuracy and undeniability.

What happens to the offline-turned-online persona when the results of their DTC genetic ancestry test appear to contradict the persona, be it a split version of the offline self or an embellished or highlighted version of the offline self? If Bullingham and Vasconcelos' (2013) work can be carried over to the world of YouTube, particularly that of professional YouTubers, the response to the contradiction may be one of conforming to social pressures, which may involve either denying the results, accepting them with caution, or accepting them wholeheartedly and taking the results in as simply another facet of, if not their offline identity, then their online YouTube identity. 


\section{Methods}

Through the following analysis I aim to answer the questions: (1) What do nonspecialists (of DTC genetic testing) focus on when receiving their DTC genetic ancestry test results?; (2) Are these non-specialists focused on explaining themselves or their own results (or the results of whomever they feature in their video) or on explaining how the testing process actually works for the benefit of their viewers?; (3) Are these videos about the DTC genetic ancestry test results one-shots, that is, individual videos independent of other similar videos, or part of a series on their own channel or a collaboration with other YouTubers, and would further investigation into these differences merit further research?; (4) Do these non-specialists specifically refer to race when making sense of their DTC genetic ancestry test results?; (5) Do the non-specialists claim to shift their identity based on the test results?; and (6) What are those same non-specialists surprised by or not surprised by when receiving their DTC genetic ancestry test results? This may be anything from the results themselves to how they received them.

To answer these questions, I carried out a narrative analysis of YouTube videos akin to studies such as Chow-White et al.'s (2018), Harris, Kelly, and Wyatt's (2014; 2016), and Mittos, Blackburn, and de Cristofaro's (2018). Like these researchers my focus is on the Reveal. As previously articulated, the Reveal in the use of DTC genetic tests is a popular feature of contemporary interactions with the tests, originally introduced by African Ancestry through television (Nelson, 2016). Chow-White et al. (2018) and Mittos, Blackburn, and de Cristofaro (2018) focused on the Reveal upon Twitter, while Harris, Kelly, and Wyatt (2014; 2016) focused on the Reveal upon YouTube, although the former focused on ancestry and the latter on health genetic testing. 
I used a purposive, non-random quota sample (Whiton, 1997) gathered through logging out of my Google account and erasing my browser's and Google and YouTube search histories, thus forcing YouTube's algorithms recommending videos to start from scratch, allowing me to initially locate YouTube DTC genetic ancestry Reveal videos through YouTube's search function by narrowing my focus to a few companies and pairing their names with search terms such as "+ genetic test”, “+ results” or "+ my results”. Initially, I focused on African Ancestry, Family Tree DNA, Ancestry DNA, and 23andMe due to the former two being two of the first DTC genetic testing companies and the first the creator of the DTC genetic ancestry test Reveal, while the latter two have thoroughly entered the YouTube environment through an abundance of advertisements, parodies, or Reveals. From this starting point I expanded my search, letting YouTube and Google's personalization algorithms recommend similar videos to me.

As in previous studies of YouTube (see Burgess \& Green, 2009; Kavoori, 2015; Strangelove, 2010) I was quickly inundated with videos and narrowed my focus further by time and uploader's age, deciding to focus only on those videos posted within 2017 or 2018, and those uploaded by a channel owned by someone over 18 that featured test recipients also over 18 . Four companies came up often: 23andMe, African Ancestry, AncestryDNA, and, surprisingly as it rarely showed up in my initial exploratory searches, MyHeritage DNA. Family Tree DNA showed up significantly less often, coming to be only 2 of the sampled videos, far below the occurrence of other companies. Due to the abundance of videos found I further narrowed my scope by focusing on videos uploaded within the first five months of 2018 to account for the holiday sales while still giving myself time to analyse the videos. Narrowing the time frame also helped in ensuring that the majority of videos were published by people who had participated in 
a similar genetic testing process, had their genes compared to a similar dataset, and had interacted with a similar website and spittoon or swab kit.

Each uploading channel was limited to one video, the most recent, except for when the channel featured a series of Reveal videos on DTC genetic ancestry test results during the first five months of 2018. In such cases all videos in the Reveal series for 2018's first five months were absorbed into the corpus to be analysed to briefly investigate whether there was a pattern in the Reveal or a common narrative across all Reveal series videos and perhaps an avenue for further research. Furthermore, I adjusted my corpus so that I had a mixture of videos that were or were not sponsored by DTC genetics companies, and a mixture of users. Building off the lessons learned from Crenshaw, Collins, and Lugones, while identifying some commonalities across the corpus is useful for articulating the corpus I am working with, I was not searching for a corpus that would tell me overall what the majority of users were doing in their Reveal videos, instead I was searching for what a mixture of users were doing, users that may be termed "minority" if featured in broader analyses of YouTube videos. For this reason, I endeavored to ensure that the videos I analysed featured people of various genders, ethnicities, and races, all features theorised to be relatively easy to infer due to the uploaders identifying themselves explicitly as a specific gender, ethnicity, and/or race. Where possible, I also attempted to include a mixture of nationalities and family histories, and for this reason I included videos put out by people who knew their biological family history and videos put out by people who did not know their biological family history. This resulted in 26 videos focused on AncestryDNA, 25 videos focused on 23andMe, 8 videos focused on MyHeritage DNA, 3 videos focused on African Ancestry, and 2 videos focused on Family Tree DNA. This count includes 4 videos that featured multiple companies. This created a total corpus of 64 videos uploaded during the first five 
months of 2018. Within this corpus there was a total of 76 individuals who took a DTC genetic ancestry test and engaged in the Reveal process on-camera (aka the test-takers), making for a total of 79 different individual reactions from test-takers with three individuals appearing multiple times in separate videos in their own series.

These videos were then coded based on multiple features to discover the type of corpus that resulted from this narrowing of time, and to ensure that the sought diversity of experiences was fulfilled. Their focused company (23andMe, Ancestry DNA, MyHeritage DNA, African Ancestry, Family Tree DNA, multiple companies), type as identified by the video itself (i.e. comparison, review, immediate reveal, delayed reveal, a mixture, other), as well as the testtaker's self-identified knowledge of their genetic ancestry (knows parents' genetic ancestry, knows grandparents' genetic ancestry, knows beyond their grandparents' genetic ancestry, does not know genetic ancestry), self-identified race (i.e. Black, White, Asian, Latinx, Indigenous Australian, Mixed, etc.), self-identified ethnicity (i.e. Armenian, British, Scottish, Nigerian, Nicaraguan, African American, Korean, etc.), and self-identified gender (i.e. male or female, non-binary, agender, other).

As explained in the previous section, race and ethnicity are included due to their popular conflation and interaction with genetic ancestry, and due to the socio-political effects race and ethnicity have had on the preservation of one's family history, making some populations more likely to know more about their genetic family ancestry than others. Gender is included for two reasons: (1) Due to the nature of the DTC genetic ancestry tests, which may trace ancestry through maternal or paternal ancestral lines, knowing a person's self-identified gender even without knowing their biological sex may help with determining whether a paternal ancestry test would have occurred, which may be important for some people; and (2) due to the gendered 
dimensions of YouTube and genealogy, there may be gendered differences in how DTC genetic ancestry test results are revealed in a YouTube video or who is actually taking the tests.

With this basis the narrative analysis was carried out through repeated viewings while taking notes and making transcripts of the videos, focused on the components identified below and the questions previously articulated. From Kavoori (2015), Lange (2008), and Vonderau (2016) I gained a deeper understanding of YouTube as a digital platform, pairing nicely with Couldry (2008), who explained that digital narratives (that is, narratives in a digital form) have patterns and logics consistent with the digital platform they are upon, which suggests that these videos should exhibit some commonalities. This leads into Gubrium and Holstein (1995; 1998), who identify multiple common components to narratives, which are supported by Nayar (2016), Oikkonen (2013), and O'Riordan's (2011) understanding of genetic testing offering distinct opportunities for narrative construction, thus bridging the path from the Reveal genre into the genre of the Reveal as part of a larger narrative.

\section{Gubrium and Holstein}

In their work on narrative analysis, Gubrium and Holstein interpreted narratives, specifically personal narratives, as "linked to the interplay" between the storytelling's context and the "discursive actions" undertaken through telling the narrative (1998, p. 164 emphasis original). As such, they built off previous work to say that narratives are examined for both information on the content and what it tells the examiner about the storyteller's life, as well as how the storyteller themselves and the context of the storytelling influences the story and its telling (Gubrium \& Holstein, 1998). From this position they analysed personal narratives and the identified interplay, finding multiple common components of narratives, including: 
developmental stages, pattern alternation, pattern elasticity, contradictory themes, sharing stories or creating linkages, substantive monitoring, and narrative ownership.

Developmental Stages. Gubrium and Holstein use Gergen's critiques of developmental stages to explain that when focusing on charting an individual's progression throughout time based on set developmental stages (ex. childhood, teenagedom, adulthood) they obscure the roles of individuals in creating and defining their own progression through such stages, constantly reinterpreting and reconstructing their stages as defined by themselves (1995, p. 208). I have applied developmental stages to my analysis by focusing on the stages that are assumed or adopted by the YouTubers as an important part of the DTC genetic testing Reveal genre. For example, Harris, Kelly, and Wyatt (2016) present the stages as: unboxing (of the swab or spittoon kit), spitting or swabbing, waiting, receiving the results, opening the results, and reacting.

Pattern Alternation and Pattern Elasticity. Pattern alternation refers to the recognition and then alternative use of patterns for interpreting or communicating an experience. Gubrium and Holstein used the example of a woman reinterpreting her experience when confronted by an alternative perspective of someone else's own similar experience; she thus used someone else's experience to make alternative sense of her own similar experience (1995, p. 213). This alternation may be due to the alternative being experienced or interpreted differently due to internal differences between the individuals or due to external differences in their environments.

Similarly, pattern elasticity refers to the ability of individuals to interpret the same experience from one perspective and place it in one sphere of understanding at one point only to change their interpretation and place the experience within a different sphere at another point 
(Gubrium \& Holstein, 1995, p. 216). Pattern elasticity accounts for multiple different interpretations of the same experience.

Pattern alternation and elasticity acknowledge the interplay between multiple people sharing their experiences, learning from their own and others' experiences, and being involved in changing environments, all of which help them to reinterpret their experiences and their value or impact on themselves and others. As YouTube is a changing community where sharing experiences is integral, uncovering the pattern alternations and elasticity that occurs across and within videos may uncover useful data.

Contradictory Themes. Briefly mentioned by Gubrium and Holstein (1998, p. 167), contradictory themes are precisely what they seem to be. They are themes in a narrative that appear to contradict or work against one another. What is intriguing is noting what these themes are, when they come up, and how the storyteller works the contradictory themes into the same story. Different storytellers may identify similar contradictory themes and work them into similar stories in entirely different ways; how this occurs is noteworthy.

Sharing Stories or Creating Linkages. Sharing stores and creating linkages are closely connected, due to the linkage creation being unable to exist without the sharing of stories. Storytellers, in this case YouTubers or test-takers, create linkages between different parts of their individual stories, creating a coherent narrative as they understand it or wish to present it, which they then post online. They may also create linkages between their story and another person's story through phrasing such as "YouTuber [blank] did a video on this and I liked theirs so here's mine!" or "I'm doing that thing you do when you're a YouTuber and like, post a video about your favourite recipes or whatever." The storytellers are both authors and editors, constantly 
reworking the story so it gets closer to what they want it to be (Gubrium \& Holstein, 1998, p. 170).

Substantive Monitoring. While storytellers are both authors and editors, they are authors and editors working from varied perspectives (their own) and in specific environments. Within different environments stories are communicated in different ways and may shift to local protocols. For example, a story told over YouTube on an entertainment channel will differ substantially from the same story told over YouTube through a news channel. They are working on the same platform, but in different environments that involve different actors (i.e. news anchors versus actors) and different audience expectations (i.e. just the facts versus drama or comedy), thus the protocols for telling stories differ. There is also an element of "formal narrative control" through the simple fact that YouTube is a place for video uploads and thus carries its own platform-specific protocols (Gubrium \& Holstein, 1998, p. 175). To work on YouTube you need an account or partnership to upload videos, which necessitates agreeing to the requirements of YouTube itself, and on YouTube there are social expectations due to its status as a site for video uploads. An upload that focuses solely on the audio and not on the visual, for example, may not be the best choice if one wants an abundance of views and likes on that upload.

Narrative Ownership. The owner of the story or narrative can quickly become complex. This is impacted by multiple features, such as genre and environment. In one environment where personal sharing is encouraged in a specific format someone may share a story one way but in another more private environment they may share only specific small components of that same story, shifting their ownership of the story while granting partial ownership to the environment, format, and even the audience. The audience may ask questions, impacting how the story is told, 
and thus claim partial ownership over the story. There is also formal ownership to consider, who may legally own a story or narrative and in what form, such as written work, audio, or visual (Gubrium \& Holstein, 1998). All these forms of ownership further impact what stories are told in the first place, with the environment perhaps denying, for example, a child, the right to speak and communicate their story 


\begin{abstract}
Analysis
There was a commonality of what I termed "Filler" material, which is either discussion of non-ancestral test results, channel specific content such as intros and outros, or other nonancestry or non-genetic content, with "filler" dominating 16 videos by an average of $18.5 \%$, but 40 of the 64 analysed videos did focus on showing the DTC genetic ancestry test results. One video was not a Reveal video and instead discussed the test-taker's ancestral history based off the results shown in a preceding video in the series, a video which functioned as the actual Reveal video.
\end{abstract}

Some videos focused on what I termed "Musings" as a catch-all term for when test-takers considered their results either alone or with others, the possibilities of genetic testing and technology, or discussed history or ancestry more broadly than focused on themselves. Another focus was "Background," used when test-takers discussed what they believed their genetic ancestral background to be. "Process" was used when test-takers demonstrated and/or explained how the testing process works, specifically the spitting or swabbing, and lastly "Advice" was used when test-takers offered advice on topics such as choosing a DTC genetic ancestry test or engaging with the results. Overall, the corpus exhibited The Mirror genre outlined by Kavoori (2015) because it functions as an archival reflection of the uploader's self with The Witness, which would function as more of a journalistic report on DTC genetic testing, unfortunately not making an appearance. This is partly due to the time restraints set on the corpus. It would be extraordinarily hard, if not impossible, to create a Witness series or video reporting on the effectiveness of various DTC genetic ancestry tests within the five-month window. Further research focused on the Reveal in The Witness genre would be valuable. 
For answering the first and second questions outlined in the Methods section, the following was found: Following Results, which appeared in 63 of the videos, and Filler (which was skewed due to the presence of 23andMe, the only company in the corpus that does offer parallel genetic health testing), which appeared in 63 of the videos but as the focus of 16 videos, Musings appeared in 47 videos and was the focus of 11. Background appeared in 45 videos and was the focus of 4, Process appeared in 29 videos and was the focus of 5, while Advice appeared in 7 videos and was the focus of 2 .

Regarding the third question, there were 5 separate series on DTC genetic ancestry testing which made for a total of 7 videos published in the first five months of 2018, while there was 1 collaboration that included 2 videos, one from each collaborator, published in the first five months of 2018. Forty-two of these 64 videos mentioned race, either through the test-taker or a guest explicitly saying "race" or by using signifiers such as skin colour to assert their own or others racial identity when predicting or reacting to their genetic ancestry test results. The use of racial terminology was used both to make sense of their results (ex. "[after seeing European ancestry] Here I am, blonde hair and all") and to explain what their backgrounds were (ex. "I feel like I'm a very racially ambiguous person" or "I mean look at me I'm probably not very Native American"). For the Black American women in the sample they often invoked race and specifically the legacies of slavery when discussing the occurrence of European ancestry in their DNA. This was invariably brief, a side comment on how that bit of European ancestry was "maybe not a good thing" or a sarcastic "thanks to a good thing called slavery", with one of the more demonstrative examples coming after one Black American woman expressed her pride in being black and finding a significant amount of African ancestry “... so this [British ancestry] is the shocker, 'cause like when I opened it this can't be right, and according to my history the only 
reason I could have this in me is because master was doing something he wasn't supposed to do with them slaves." Overall, there were 20 white test-takers, 18 Black test-takers, 16 Asian testtakers, 14 Mixed test-takers, 3 Latinx, and 5 Unclear.

Forty-seven out of the 79 individual reactions addressed the issue of self-identity. Only 11 individual reactions were found where the test results were said to alter the test-taker's selfidentity, while 32 of 47 individual reactions said their results did not alter their self-identity, and an equal number of reactions (32 of 79 individual reactions) did not address the issue of selfidentity at all. The remaining 4 of 47 individual reactions were unclear on how, if at all, their test results impacted their self-identity, leaving the inquiry of question five up in the air. Related, and to answer question six, there were 33 individual reactions expressing No Surprise upon seeing their test results, 28 individual reactions showed surprise about only One Part of their test results, such as a percentage point that seemed off or an ethnicity they hadn't expected, and 17 individual reactions showed surprise about Most of their test results, clearly expressing this surprise as they excitedly scrolled through or reflected on their genetic ancestry report. Finally, a single video featured 1 individual reaction to uncovering a long-buried family secret regarding their biological relations, which encompassed a level of surprise unmatched in the corpus.

\section{Gubrium and Holstein}

How the corpus engages with Gubrium and Holstein's (1995 \& 1998) narrative themes is outlined below. While separated by the different narrative themes, due to the nature of the themes there will be some crossover and interplay.

Developmental Stages. As Harris, Kelly, and Wyatt (2016) determined, the traditional stages of a DTC genetic testing video are: unboxing (of the swab or spittoon kit), spitting or swabbing, waiting, receiving the results, opening the results, and reacting. While some videos 
provided a kind of prologue to the Reveal, revealing that they had seen the results beforehand and wanted to preface their reaction to explain that, most of the videos proceeded roughly along the stages outlined by Harris, Kelly, and Wyatt. Those videos that incorporated information on the Process (29 of 64 videos) provided the most classic example of the stages, despite not often showing footage of the DNA sample collection process with many deeming the process "disgusting", they did explain the process. Some who incorporated the Process used material from the company websites or, in the case of sponsorship, from conversation with the company, to explain how the DTC genetic testing process occurred. For example, one test-taker explained that "if you share DNA segments with 5 or more individuals from that country" you're said to be part of that population while in a different video a test-taker specifically explained that they were in conversation with the DTC genetic testing company and identified onscreen with a bell sound or a visual note whenever they were saying something from that company or were saying something that was their opinion. Due to adhering to an already present digital narrative structure, the test-takers participated in the standardization of the Reveal genre upon YouTube, making it easier for the audience to view and understand their videos (Couldry, 2008).

Pattern Alternation and Pattern Elasticity. Two primary cases of pattern alternation and pattern elasticity showed up in the corpus, building off Lee and Crowley's (2009) work suggesting that genetic information can be used to help create ties between people. The first I'm referring to as "The Classics" because it involved test-takers espousing about how they decided to upload their results and Reveal to YouTube because they saw others do it. These videos followed the rough stages outlined above and would briefly comment on their inspiration for uploading the videos. For example, one test-taker commented, "I was obsessed with watching all the videos out there on YouTube about people's results...I found the YouTube videos super- 
helpful in helping me navigate what that [DTC genetic testing] world is..." while another said, "We're just gonna do that stereotypical YouTuber thing and find out what exactly I am on the inside." They took their cues from "The Classics" uploaded earlier and engaged with them, if only briefly, to create their own take on the "stereotypical YouTuber thing." Thus, a tie was created through engagement with their own genetic information.

The second is "The Culture Groups" which refers to the conversation occurring amongst members of similar cultural or socio-historical groups as they explore their test results. The primary variation on The Culture Groups was found amongst the Black American test-takers, who identified as Americans descended from dominantly West Africans brought to America during the slave trade. Out of a total of 76 test-takers there were 21 "Black Americans", a group combining 16 people who identified as Black or African American and 5 people who identified as Mixed but focused on their Black American identity for the video. This prominence of Black American test-takers grappling with a similar issue was unsurprising, due to the difficulty of getting information on their ancestors brought to America as slaves, and due to the work of scholars such as Alondra Nelson in exploring and explaining the growth of genealogy amongst Black Americans.

There were common themes the Black Americans grappled with in the corpus, starting with a lack of knowledge about their ancestry and moving into their expectations of the test, with none of the Black Americans in the corpus expecting to be $100 \%$ African. Instead, the majority (16 of 21) believed that it would show how "mixed" they were, and the remaining 5 didn't theorize about their results prior to seeing them at all.

Furthermore, there were 2 individuals who identified as part of specific African peoples (ex. Maasai). Despite not identifying as Black Americans or carrying the history of slavery that 
resulted in Black Americans not knowing about their ancestry, they nevertheless engaged with the conversations Black Americans were having. Both sought to provide aide or advice for Black Americans, either through the act of taking the DTC genetic ancestry test in the hopes that their DNA would help improve the genetic data on the DNA of their people and in turn help Black Americans gain more information on their ancestries, or through providing advice on how to prepare for receiving one's results, such as through researching various African peoples, communities, and histories. The former individual's reasoning for participating in the genetic ancestry test and engaging with the conversations Black Americans were and are having is a clear example of Lee and Crowley's (2009) assertion of genetic information creating ties between people. All those who engaged with the conversations Black Americans were having were ultimately seeking to help Black Americans gain more knowledge of their ancestries, either through engaging directly with genealogy or genetic services themselves or through encouraging Black Americans to engage with genealogy or genetics services themselves.

Contradictory Themes. Eighteen of the 64 sampled videos showed contradictory themes, with the majority, 11 , showing these contradictory themes through the issue of unexpected results. The unexpected results showed up when a test-taker theorized about their genetic ancestry results and then found that their actual results revealed something entirely or partially different. The test-takers were split on how they responded to these results. Some, in the case of those whose results were only partially different, took in the different results by saying something along the lines of "I feel in my heart [a kinship to this culture]" or by applying elements of themselves to the unexpected ancestry, often using stereotypes to justify the unexpected results. In the case of those whose results were largely different than what they expected, they turned to the culture they were raised in for assertion that they were a part of that 
population or suggested the test was either "bad" or not $100 \%$ accurate. There were others who, whether they got only partially or largely different results, simply took it in with good humour, commenting along the lines of: "I think it's sick...I used to have like a clear answer when people say like, what's your background, and now I'm just gonna say I dunno I'm a lot of stuff." All incorporated multiple reactions to the unexpected results. For example, one test-taker took in the unexpected results with excitement but repeatedly commented on how "crazy" they were, betraying their remaining discomfort. There was 1 outlier in this group whose unexpected results arose from both a portion of unexpected ancestral results and a misunderstanding regarding sibling genetic inheritance. The misunderstanding was only briefly commented upon in the video, with the portion about the unexpected ancestral results taking up most of the video.

Six videos showed test-takers providing contradictory themes in their language by equating genetics with appearance, ethnicity, culture, or nationality. While genetics do impact your appearance the 4 who equated them did so in a stereotypical manner by simultaneously connecting appearance with ethnicity, asserting that they "look like" or have been told that they "look like" a specific ethnicity. Two did not recognize that they created a contradiction by equating genetics with appearance with ethnicity, having commented on how others don't look like an ethnicity and others do, while the other 2 did recognize the contradiction but nevertheless pressed on with it. The remaining 3 didn't comment on appearance in a manner that created a contradictory theme, but they did comment on genetics and culture or nationality in a way that did. Two did so with no apparent awareness that culture is not determined by genetics, though based on the rest of the videos 1 likely intended such assertions to be taken not as contradictory but as suggestions for where to start to find one's culture, and the other likely intended it to be taken as an expression of their feeling of rootlessness. The last video featured a test-taker who 
created the contradiction purposefully, debating about the contradictions that come up with dual citizenship and multiple ancestral threads, before ending the video by consciously leaving any resolution up in the air. This was also the only video in the entire corpus that engaged with the conversation about nationality, culture, and genetics in-depth.

Sharing Stories and Creating Linkages. Sharing stories and creating linkages is related in this case to pattern alternation and pattern elasticity because some test-takers explicitly stated that they were inspired to post their own Reveal after viewing other people's Reveals. It's also related to developmental stages because all but one of the videos analysed followed, roughly, the stages already found in the Reveal genre upon YouTube.

One explicit engagement with sharing stories and creating linkages was in the collaboration. The two YouTubers involved collaborated in creating a video each, and while it's unclear how much collaboration they engaged in during the creation of the videos, they clearly influenced how the other person's video would develop. They spoke back to their collaborator in their individual video by saying things such as, "let's answer the questions from [Collaborator]", or “Once you finish watching my video, go ahead and click above my head, [Collaborator's] link to [Collaborator's] video with me", or "Me and [Collaborator] decided to go ahead and share what we think...our ancestry...will say". Through the mechanisms offered by YouTube they publicized their socialization with one another (Lange, 2008), exploring their individual test experiences in a collaborative manner to create a shared story that crossed channels.

Substantive Monitoring. There appears to be little substantive monitoring occurring, beyond that offered by YouTube and the DTC genetic testing companies as services, platforms, and communities themselves. In 2 videos the test-takers engaged specifically with this type of monitoring, both talking about what YouTubers typically do and how they will either conform to 
that or not, though in the case of the latter not for lack of want to conform. Furthermore, unlike earlier studies of YouTube vlogs (see Harris, Kelly \& Wyatt, 2016) the test-takers responded to the substantive monitoring offered by the community by dominantly presenting more professional looking, visual inserts, pop-ups, and "sets" paired with professional video unlike earlier vlogs, which were most often filmed in messy rooms or exteriors with glaring sun (Goffman, 1959, p. 245).

One interesting case of substantive monitoring is when the test-takers engaged in advice giving. As seen previously, only 7 videos incorporated Advice and only 2 of those focused on giving Advice. Both gave advice on how to approach the DTC genetic ancestry testing, advising engaging with other people and doing independent research. They were working against the expectation of the Reveal genre, where the focus is on the results rather than what the test-taker can do prior to taking the test, and as such they were working against the expectations of the audience of the Reveal genre, in effect working against the substantive monitoring presented by the audience.

A second interesting case of substantive monitoring was when the videos were part of a series or collaboration. In the case of the series there's an expectation amongst the audience that each video in the series will look like the others. In the case of the two series I looked at that posted two videos each in the allotted time this expectation held up. Both videos looked as though they were part of a series, even without being formally titled “\#1” or “\#2”. Further research is needed to determine whether this carries through other video series.

Similarly, the lone collaboration provided an example of substantive monitoring in that the collaborators engaged with one another to create their individual videos, providing questions to one another that they could address at the end of their video. Due to this substantive 
monitoring the videos that were part of a collaboration followed the rough developmental stages of: introduction, background, speculation of results, process, reveal, reaction, and answering collaborator's questions.

Narrative Ownership. Each test-taker can assert ownership over their own narrative as it is presented in the uploaded video, however, this ownership is complicated by the presence of multiple actors. Besides the test-taker, there are also the companies, both YouTube and the DTC genetic testing company they engage with. Both companies can assert a kind of ownership over the narrative, because without their presence there may not have been a video in the first place, and the video may not have been presented as it was, such as with screenshots of the testing results appearing in the video alongside the test-taker's face. Alongside this comes the company that produced whatever video editing software the test-taker used to create their uploaded video.

Furthermore, there is the Reveal genre itself and the audience it has developed. The genre requires certain components in the narrative to be part of the Reveal genre. Namely, it requires a reveal of some kind. If I engaged with the comments accompanying each video the commenters themselves would have to be considered as partial owners as well, because, particularly in cases where the test-taker asks for comments of a particular kind (i.e. "Comment below so we have some dialogue about our DNA results and we have some connections" or "...leave a comment down below if you've done yours already or what you think yours is gonna be"), they're helping to create a narrative around the video, which may impact how the audience engages with the video. These cases of ownership were rarely addressed, except in the case of the sponsored videos, where the YouTuber identified that it was sponsored and thanked the sponsor for sponsoring them. Only 23andMe and MyHeritage sponsored videos in this corpus, and out of the 64 individual videos there were 10 sponsored, while 6 were unclear regarding sponsorship and 
the remaining 48 were emphatically not sponsored. Only one of those sponsored videos had a test-taker who scattered the information they got from the sponsor throughout the video and specifically identified all the information they got from the sponsor. The other sponsored videos took a more laissez-faire approach, reading from a printout from the sponsor or having a brief section of the video where they explained what the sponsor provided them with. 


\section{Discussion}

\section{Gender}

Matching Nelson's (2016) assertion that genealogy is dominantly a female pursuit, most test-takers (54 of 76) were female, with the remaining 22 test-takers being male and zero testtakers identifying outside or elsewhere along the gender spectrum. Furthermore, there was no case of multiple male test-takers being in the same video without a female test-taker also featuring. Instead, whenever there were multiple test-takers there was always at least one female. There were 9 female and male pairs, 6 of which featured both individuals taking genetic ancestry tests while the remaining 3 featured only the female individual taking a genetic ancestry test while the male served as a kind of witness. Female test-takers therefore took on the brunt of the genealogical and genetic responsibility, preserving online the evidence of their ancestry and genetic relations. The one outlier was in the case of a Reveal video produced by a large media company rather than a small YouTube business or non-monetized YouTube channel, which dominated the corpus. This outlier featured three times the number of males than females and all were test-takers.

Furthermore, there was less of an emphasis on parenthood, and specifically motherhood, than expected. While all test-takers spoke of their own parents due to their presence as part of their genetic ancestry, only 3 test-takers specifically talked about their existing or future children, suggesting that the importance of reproduction and biological parenthood, or specifically

biological motherhood, is one that holds little interest for the sampled population at this moment. Further research on considerations about genetic ancestry and parenthood would be valuable, as it may be useful for interrogating the importance of both amongst different generations, cultures, and environments (see also Crouch, Yu, Shanker \& Tabor, 2015). 


\section{Genetic Options Theory and Identity Multiplicities}

Some components of genetic options theory can be found in this sample, most notably amongst the white-identifying test-takers. According to Roth and Ivemark (2018), due to their status at the top of racialized society where their racial identity is treated as invisible, or in Lugones's (1994) language their identity is treated as pure and singular rather than comprised of multiplicities, white test-takers are more likely to see their white identity as lacking culture or being bland and thus they may seek a non-white component to their identity. This was briefly suggested in the analysed sample, with 2 of the 20 white test-takers expressing boredom when their genetic ancestry results showed nearly or all European ancestry. In contrast, while the white test-takers appeared to be seeking some non-European ancestry, no matter how small, most of the test-takers who identified as black or Asian were more interested in finding confirmation of their black or Asian identity, with Black Americans specifically hoping for $60 \%$ to $80 \%$ African ancestry, other black test-takers seeking confirmation of their self-identified ethnicity (ex.

Cameroonian) or the appearance of other African ethnicities, and Asian test-takers expecting and even hoping for their results to show that they were $99 \%$ or $100 \%$ their self-identified ethnicity (ex. Chinese). Asian test-takers showed significant surprise when anything besides their selfidentified ethnicity (ex. Indian) was found, with 9 of the 16 Asian test-takers expecting to get results showing only a single ancestry while 5 expected mixing and 2 didn't theorize at all. Four of the 20 white test-takers expected a similar $100 \%$ result, however their $100 \%$ expectation was not focused on a specific ethnicity (ex. French) as the Asian test-takers were, instead their 100\% expectation was focused on a continent, specifically Europe. Contrastingly, the test-takers who identified as Latinx, Mixed, or with an ethnicity (not race) that had multiple populations historically mingling within it, the expectation was always that there would be varied results. 
Therefore, while most test-takers expressed no identity change ( 32 of the 47 people who addressed it), either because they felt no need to have one or due to the societal pressures that would come with expressing such a change on a YouTube video, the sample that did (11 of the 47 people who addressed it) complicates Roth and Ivemark's (2018) assertions. This is because 4 of those that did express an identity change were black, comprising $36 \%$ of the reactions from black test-takers who addressed the possibility of an identity change. In contrast, only 2 of the 11 expressing an identity change were white, comprising $14 \%$ of the reactions from white testtakers addressing the matter. However, while the reactions from black test-takers were evenly divided between expressing an identity change and not expressing an identity change (4 each), they did not express that change by entirely reinventing their self-identity. Instead, they incorporated the varied results into their existing self-identity. In the videos this did not appear to alter their overall self-identification as, for example, Black Americans. What the results did instead was flesh out their self-knowledge and understanding of their biological family's history.

This approach to DTC genetic ancestry results carried across nearly all test-takers.

During the Reveal videos test-takers simply took in the results and adopted what Lugones' (1994) would call a thick identity or a recognition of their multiplicities. Only 7 of 79 individual reactions did not involve adopting a thick identity, with 1 of those individuals ending the video before they cycled past their shock regarding their results to a point where they did grapple with their identity, 1 individual implying that they were adopting a major new result as their only identity, and 5 individuals finding that their results were nearly exactly as expected and, if there was one, choosing to reject any negligible (less than 5\%) result that was not expected. The latter 6, despite being marked as thick in the North American societies in which they identify as living, appeared to seek not to be identified as thick in their own racial or cultural communities. These 6 
individuals all identified racially as Asian and as having Asian ethnic backgrounds, giving some weight to the idea espoused both by another Asian test-taker and by Roth and Ivemark that many people who identify racially as Asian operate under the assumption that "most Asians are not racially mixed" or that because they're more likely to be first or second-generation immigrants to North America "they may feel more confident of their ancestral origins than other [North] Americans" (2018, p. 162).

Similarly, only 12 of 79 individual reactions did not involve adopting an identity that involved multiplicities. Again, 1 ended the video before they could cycle past their shock and grapple with their identity and along with 6 others were the same individuals who rejected any thickness and therefore multiplicity regarding their ancestry. The remaining 5, while recognizing their thickness and keeping it open for them to experiment with later, chose to focus on one portion of their results during the video and thus did not invoke their multiplicities in the video.

Curdling and fragmentation were split relatively equally, Thirty-nine of 79 reactions involved curdling, such as when explicitly identifying their ancestry as a mixture, and 40 of 79 reactions involved fragmentation, such as when identifying with a single part or a select few parts of their genetic ancestry rather than the whole. The single occurrence of curdling without fragmentation involved the test-taker taking in all their results and not finding any need to disarticulate any part of them to present themselves. Two occurrences of fragmentation without curdling involved the test-takers becoming fragmented upon receiving their results, even commenting on the fragmentation as they struggled with figuring out their identity, but in the videos they never quite managed to coalesce the disparate fragments and curdle.

Lugones (1994) asserted that she wanted a society comprised of non-fragmented people where their multiplicities of race, culture, gender, and other differences impacted themselves and 
others, coexisted, even coalesced, in a rejection of transparency. With only 12 of 79 reactions asserting their transparency after receiving and absorbing their results, this would seem to be within reach as far as reactions to genetic ancestry test results are concerned. Indeed, most testtakers entered the testing expecting a multiplicity; in the case of Black Americans this was a multiplicity of African and European ancestry, and for Mixed and Latinx test-takers it was a combination of multiple continents. Only 4 of the 20 white test-takers expected to be $100 \%$ of a specific European ancestry, with the rest expecting multiplicities primarily of European ancestries, while most of the Asian test-takers expected to be $100 \%$ of a specific Asian ancestry, the only population to have most expecting $100 \%$ of anything. The majority test-takers reacted positively to their results' multiplicities, only 4 revealing to be bored by their results and a single test-taker finding their results disappointing. Excitement and surprise were common, test-takers finding discovering their genetic ancestry to be an engaging endeavour and often recommended.

Amina Mama's idea of dynamic identity is valuable here, as it interacts well with Lugones' (1994) ideas of curdling and multiplicity alongside Roth and Ivemark's (2018) genetic options theory and Goffman's (1959) ideas about identity presentation. Mama (1995) cited multiple times the occurrence of her research participants adjusting their identity and how they presented their identity based on the environment and people around them. We can see that in these Reveal videos because test-takers engage directly with their identities on multiple levels, starting with their own beliefs and family histories, moving on to a competing or confirming set of facts, reconciling those facts with their beliefs and histories, and finally grappling with the idea that the facts may change as the tests and data pools change. Some would engage directly with their environment, asking their audience to guess what ancestries they were, or to comment with their genetic ancestry test results, but most would only briefly attempt to engage with their 
results beyond simply reading them aloud. They would comedically experiment with their identity presentation, many seeking to entertain as well as inform. To do this the test-takers would engage specifically with ancestral identity signals in a manner similar to that performed by YouTubers in Smith (2014). They would engage with identity signals ranging from adopting accents and singing songs, to displaying stereotypical symbols of various ancestries onscreen (ex. sausages for German ancestry), to showing the flags or geographical boundaries of the countries their ancestries are associated with, or even deciding "we have to learn all the national anthems of these [new ancestral] countries now."

\section{Conclusion}

Akin to Bullingham and Vasconcelos's (2013) and Strangelove's (2010) findings on the Internet and YouTube respectively, the videos examined here seemed to be extensions of conversations occurring not only elsewhere on YouTube but elsewhere online and offline. Even without looking at the ever-growing batches of news articles and blog posts on DTC genetic ancestry testing, the patterns, ranging from the conversations Black Americans are having about their ancestry and identities to the white test-takers' vague articulation of "European ancestry" and the Asian test-takers' surprise and discomfort if anything new comes up, suggest that there are broader conversations occurring elsewhere that produce these reactions and expectations. While applying any findings from such a small sample to a larger one is unwise, the literature surrounding these topics does support the idea that such broader conversations are and will continue to occur. These conversations may not be about genetic ancestry specifically, but are likely about culture, race, ethnicity, family, and stories, and where all five intersect.

Test-takers have purchased the information about their biology from various companies and then used them to help inform their own identities. In opposition to the essentialist language 
used by DTC genetic testing companies, test-takers approach the ancestry findings with caution and a critical eye, adopting some, rejecting others, and refashioning their identities in response, thus acting as autobiogenographers and autobiologists because they are using their own biochemistry to fashion and refashion their identities (Nayar, 2016 \& 2017; Nordgren \& Juengst, 2009). Rather than approaching their genetic information as information, they approach it as a tool used for grappling with their own identities (Postan, 2016). Posting this grappling online turns the individual or even familial activity into a public one, opening the floor for questions and comments, and the possibility of expanding into a series or collaboration. Whether the grappling continues in such avenues - comments, series, or collaborations - is another avenue entirely for further research into how test-takers respond to and reveal their genetic information, personal and familial history, race, and culture, to the Internet surfing public.

YouTube's impression of being a space primarily comprised of white men is pushed at by these videos, giving support to the idea that within different YouTube communities there's a much more complicated breakdown and diverse conversations and experiences occurring, akin to those experiences Díaz (2012) investigated when she brought forward the lives of Roger Arliner Young, Chien-Shiung Wu, and Sor Juana Inés de la Cruz. Nevertheless, this study by no means an exhaustive analysis of these diverse conversations and experiences with DTC genetic ancestry tests on YouTube. Instead, through it I hope to push forward the opportunity to engage further with the interactions between race, culture, ethnicity, family, stories, and genetic ancestry as experienced and expressed by individuals who historically may not have had their perspectives on such topics respected or seriously considered. 


\section{References}

Ancestry. (2016, June 13). Ancestry Stories: Kyle [video]. Retrieved from

https://www.youtube.com/watch?v=84LnTrQ2us8\&index=5\&list=PL0xuz8BBkD4i23R SnZl_p6hO1CJz7-RKU.

Anderson, E. E., \& Wasson, K. (2015). Personal narratives of genetic testing: Expectations, emotions, and impact on self and family. Narrative Inquiry in Bioethics, 5(3), 229-235. doi: 10.1353/nib.2015.0062

Angier, N. (2000, August 22). Do races differ? Not really, DNA shows. The New York Times. Retrieved from https://archive.nytimes.com/www.nytimes.com/library/national/science/082200scigenetics-race.html.

Baptista, N. M., Christensen, K. D., Carere, D. A., Broadley, S. A., Roberts, J. S., \& Green, R. C. (2016). Adopting genetics: Motivations and outcomes of personal genomic testing in adult adoptees. Genetic Medicine, 18(9), 924-932. doi: 10.1038/gim.2015.192

Bates, B. R., Templeton, A., Achter, P. J., Harris, T. M., \& Condit, C. M. (2003). What does "a gene for heart disease" mean? A focus group study of public understandings of genetic risk factors. American Journal of Medical Genetics, 119A(2), 156-161.

Bates, B. R., \& Harris, T. M. (2004). The Tuskegee study of untreated syphilis and public perceptions of biomedical research: A focus group study. Journal of the National Medical Association, 96(8), 1051-1064.

Bates, B. R., Poirot, K., Harris, T. M., Condit, C. M., \& Achter, P. J. (2004). Evaluating directto-consumer marketing of race-based pharmacogenomics: A focus group study of public understandings of applied genomic medication. Journal of Health Communication, 9(6), 541-559. doi: 10.1080/10810730490882720

Bates, B. R., (2005). Public culture and public understanding of genetics: A focus group study. Public Understanding of Science, 14(1), 47-65. doi: 10.1177/0963662505048409

Bates, B. R., Lynch, J. A., Bevan, J. L., \& Condit, C. M. (2005). Warranted concerns, warranted outlooks: A focus group study of public understandings of genetic research. Social Science \& Medicine, 60(2), 331-344. doi: 10.1016/j.socscimed.2004.05.012

Bevan, J. L., Lynch, J. A., Dubriwny, T. N., Harris, T. M., Achter, P. J., Reeder, A. L., \& Condit, C. M. (2003). Informed lay preferences for delivery of racially varied pharmacogenomics. Genetics in Medicine, 5, 393-399. doi:

10.1097/01.GIM.0000087989.12317.3F

Bever, L. (2018, April 3). A woman says an Ancestry.com DNA test revealed her father - her parents' fertility doctor. The Washington Post. Retrieved from 
https://www.washingtonpost.com/news/to-your-health/wp/2018/04/03/a-woman-said-anancestry-com-dna-test-told-her-she-had-a-different-father-her-parents-fertilitydoctor/?utm_term=.92f8e825933a.

Bliss, C. (2015). Science and struggle: Emerging forms of race and activism in the genomic era. The ANNALS of the American Academy of Political and Social Science, 661(1), 86-108. doi: $10.1177 / 0002716215587687$

Bollinger, J. M., Green, R. C., \& Kaufman, D. (2013). Attitudes about regulation among directto-consumer genetic testing customers. Genetic Testing and Molecular Biomarkers, 175(5), 424-428. doi: 10.1089/gtmb.2012.0453

Bolnick, D. A., Fullwiley, D., Duster, T., Cooper, R. S., Fujimura, J. H., Kahn, J., Kaufman, J. S., Marks, J., Morning, A., Nelson, A., Ossorio, P., Reardon, J., Reverby, S. M., \& TallBear, K. (2007). The science and business of genetic ancestry testing. Science, 318(5849), 399-400. doi: 10.1126/science.1150098

Boodman, E. (2017, August 16). White nationalists are flocking to genetic ancestry tests. Some don't like what they find. StatNews. Retrieved from https://www.statnews.com/2017/08/16/white-nationalists-genetic-ancestry-test/.

Braun, L., Fausto-Sterling, A., Fullwiley, D., Hammonds, E. M., Nelson, A., Quivers, W., Reverby, S. M., Shields, A. E. (2007). Racial categories in medical practice: How useful are they? PloS Medicine, 4(9), 1423-1428.

Brown, K. V. (2018 January 16). How DNA testing botched my family's heritage, and probably yours, too. Gizmodo. Retrieved from https://gizmodo.com/how-dna-testing-botched-myfamilys-heritage-and-probab-1820932637.

Bullingham, L., \& Vasconcelos, A. C. (2013). “"The presentation of self in the online world': Goffman and the study of online identities.” Journal of Information Science, 39(1), 101112. doi: $10.1177 / 0165551512470051$

Burgess, J., \& Green, J. (2009). YouTube: Online video and participatory culture. Cambridge, UK: Polity Press.

Byrd, W. C., \& Ray, V. E. (2015). Ultimate attribution in the genetic era: White support for genetic explanations of racial difference and policies. The ANNALS of the American Academy of Political and Social Science, 661(1), 212-235. doi: $10.1177 / 0002716215587887$

Calafell, F., \& Larmuseau, M. H. D. (2017). The Y chromosome as the most popular marker in genetic genealogy benefits interdisciplinary research. Human Genetics, 136(5), 559-573. doi: 10.1007/s00439-016-1740-0 
Carbado, D. W., Crenshaw, K. W., Mays, V. M., \& Tomlinson, B. (2013). Intersectionality: Mapping the movements of a theory. Du Bois Review, 10(2), 303-312. doi: 10.1017/S1742058X13000349

Carere, D. A., Couper, M. P., Crawford, S. D., Kalia, S. S., Duggan, J. R., Moreno, T. A., Mountain, J. L., Roberts, J. S., \& Green, R. C. (2014). Design, methods, and participant characteristics of the impact of personal genomics (PGen) study, a prospective cohort study of direct-to-consumer personal genomic testing customers. Genome Medicine, 6(12), 96-106. doi: 10.1186/s13073-014-0096-0

Childerhose, J. E. (2008). Genetic discrimination: Genealogy of an American problem (Doctoral dissertation). Retrieved from ProQuest Dissertations Publishing, (\#NR66431).

Chow-White, P. (2008). The informalization of race: Communication technologies and the human genome in the digital age. International Journal of Communication, 2, 1168-1194.

Chow-White, P., Struve, S., Lusoli, A., Lesage, F., Saraf, N., \& Oldring, A. (2018). 'Warren Buffet is my cousin': Shaping public understanding of big data biotechnology, direct-toconsumer genomics, and 23andMe on Twitter. Information, Communication \& Society, 21(3), 448-464. doi: 10.1080/1369118X.2017.1285951

Christensen, K. D., Roberts, J. S., Royal, C. D. M., Fasaye, G., Obisesan, T., Cupples, L. A., Whitehouse, P. J., Butson, M. B., Linnenbringer, E., Relkin, N. R., Farrer, L., CookDeegan, R., \& Green, R. C. (2008). Incorporating ethnicity into genetic risk assessment for Alzheimer disease: The REVEAL study experience. Journal of Medical Genetics, 10(3), 207-214.

Chung, E., Glanz, M., \& Adhopia, V. (2018, January 26). Donor-conceived people are tracking down their biological fathers, even if they want to hide. $C B C$ News. Retrieved from http://www.cbc.ca/news/technology/sperm-donor-dna-testing-1.4500517.

Collins, P. H. (2000). Blackfeminist thought: Knowledge, consciousness, and the politics of empowerment (2nd edition). New York: Routledge.

Condit, C. M. (1999). How the public understands genetics: Non-deterministic and nondiscriminatory interpretations of the "blueprint" metaphor. Public Understanding of Science, 8(3), 169-180.

Condit, C., \& Bates, B. (2005). How lay people respond to messages about genetics, health, and race. Clinical Genetics, 68(2), 97-105. doi: 10.111/j.1399-0004.2005.00480.x

Condit, C. M., Bates, B. R., Galloway, R., Givens, S. B., Haynie, C. K., Jordan, J. W., Stables, G., \& West, H. M. (2002). Recipes or blueprints for our genes? How contexts selectively activate the multiple meanings of metaphors. Quarterly Journal of Speech, 88(3), 202325. 
Condit, C. M., \& Condit, D. M. (2001). Blueprints and recipes: Gendered metaphors for genetic medicine. Journal of Medical Humanities, 22(1), 29-39.

Condit, C. M. (2009). Dynamic feelings about metaphors for genes: Implications for research and genetic policy. Genomics, Society and Policy, 5(3), 44-58.

Copeland, L. (2017, July 27). Who was she? A DNA test only opened new mysteries. The Washington Post. Retrieved from https://www.washingtonpost.com/graphics/2017/lifestyle/she-thought-she-was-irishuntil-a-dna-test-opened-a-100-year-old-mystery/?utm_term=.0590f1b8b1a3 .

Corpas, M. (2012). A family experience of personal genomics. Journal of Genetic Counseling, 21, 386-391. doi: 10.1007/s10897-011-9473-7

Couldry, N. (2008). Mediatization or mediation? Alternative understandings of the emergent space of digital storytelling. New Media \& Society, 10(3), 373-391. doi:

$10.1177 / 1461444808089414$

Covolo, L., Rubinelli, S., Ceretti, E., \& Gelatti, U. (2015). Internet-based direct-to-consumer genetic testing: A systematic review. Journal of Medical Internet Research, 17(12), 1-19. doi: 10.2196/jmir.4378

Crenshaw, K. (1989). Demarginalizing the intersection of race and sex: A black feminist critique of antidiscrimination doctrine, feminist theory, and antiracist politics. The University of Chicago Legal Forum, 139-168.

Crenshaw, K. (1991). Mapping the margins: Intersectionality, identity politics, and violence against women of color. Stanford Law Review, 43(6), 1241-1299.

Crenshaw, K. (2011). Twenty years of critical race theory: Looking back to move forward. Connecticut Law Review, 43(5), 1253-1352. doi: 10.1525/sp.2007.54.1.23

Crouch, J., Yu, J., Shanker, A. G., \& Tabor, H. K. (2015). "We don’t know her history, her background": Adoptive parents' perspectives on whole genome sequencing results. Journal of Genetic Counseling, 24(1), 67-77. doi: 10.1007/s10897-014-9738-z

Díaz, S. P. (2012). Gender, race, and science: A feminista analysis of women of color in science (Doctoral dissertation). Retrieved from UMI Dissertation Publishing, and ProQuest LLC. (\#3521458).

Duster, T. (2012). Troy Duster interviewed by Alondra Nelson. Public Culture, 24(2), 283-302. doi: $10.1215 / 08992363-1535507$

Edmonds, P. (2018, April). These twins, one black and one white, will make you rethink race. National Geographic. Retrieved from https://www.nationalgeographic.com/magazine/2018/04/race-twins-black-white-biggs/. 
Eig, J. (2014). The birth of the pill: How four crusaders reinvented sex and launched a revolution. New York: W.W. Norton \& Company, Inc.

Fausto-Sterling, A. (2002). Gender, race, and nation: The comparative anatomy of "Hottentot" women in Europe, 1815-17. In K. Wallace-Sanders (Ed.), Skin deep, spirit strong: The black female body in American culture (pp. 66-95). Michigan: University of Michigan Press.

Fetters, A. (2018, May 18). Finding the lost generation of sperm donors. The Atlantic. Retrieved from https://www.theatlantic.com/family/archive/2018/05/sperm-donationanonymous $/ 560588 /$.

Frank, R. (2015). Back to the future? The emergence of a geneticized conceptualization of race in sociology. The ANNALS of the American Academy of Political and Social Science, 661(1), 51-64. doi: 10.1177/0002716215590775

Frudakis, T., Bolnick, D. A., Fullwiley, D., Marks, J., Reverby, S. M., Kahn, J., TallBear, K., Reardon, J., Cooper, R. S., Duster, T., Fujimura, J. H., Kaufman, J. S., Morning, A., Nelson, A., \& Ossorio, P. (2008). The legitimacy of genetic ancestry tests [with response]. Science, 319(5866), 1039-1040.

Goffman, E. (1959). The presentation of self in everyday life. New York: Anchor Books, Random House Inc.

Gubrium, J. F., \& Holstein, J. A. (1995). Life course malleability: Biographical work and deprivatization. Sociological Inquiry, 65(2), 207-223. doi: 10.111/j.1475682X.1995.tb00413.x

Gubrium, J. F., \& Holstein, J. A. (1998). Narrative practice and the coherence of personal stories. The Sociological Quarterly, 39(1), 163-187. doi: 10.111/j.1533-8525.1998.tb02354.x

Hacking, I. (2006). Genetics, biosocial groups \& the future of identity. Daedalus, 135(4), 81-95.

Haraway, D. (1989). Primate visions: Gender, race, and nature in the world of modern science. New York: Routledge.

Harding, S. (2008). Sciences from below: Feminisms, postcolonialities, and modernities. United States: Duke University Press.

Harmon, A. (2010, April 21). Indian tribe wins fight to limit research of its DNA. The New York Times. Retrieved from https://www.nytimes.com/2010/04/22/us/22dna.html.

Harper, J. C., Kennett, D., \& Reisel, D. (2016). The end of donor anonymity: How genetic testing is likely to drive anonymous gamete donation out of business. Human Reproduction, 31(6), 1135-1140. doi: 10.1093/humrep/dew065 
Harris, C. I. (1993). Whiteness as property. Harvard Law Review, 106(8), 1707-1791.

Harris, A., Wyatt, S., \& Kelly, S. E. (2013). The gift of spit (and the obligation to return it): How consumers of online genetic testing services participate in research. Information, Communication \& Society, 16(2), 236-257. doi: 10.1080/1369118X.2012.701656

Harris, A., Kelly, S., \& Wyatt, S. (2014). Autobiologies on YouTube: Narratives of direct-toconsumer genetic testing. New Genetics and Society, 33(1), 60-78. doi:

$10.1080 / 14636778.2014 .884456$

Harris, A., Kelly, S., \& Wyatt, S. (2016). CyberGenetics: Health genetics and new media. New York: Routledge.

Havasupai Tribe of Havasupai Reservation v. Arizona Board of Regents, 1 CA-CV 07-0454 and 1 CA-CV 07-0801 (Ariz. Ct. App. 2008). Retrieved from https://caselaw.findlaw.com/azcourt-of-appeals/1425062.html.

Helix. (2017, November 17). You could have different ancestry than your biological siblings. How? Helix blog. Retrieved from https://www.helix.com/blog/sibling-ancestry-dnatesting-kits/.

Hubbard, R. (2014). Science, power, gender: How DNA became the book of life. In M. Wyer, M. Barbercheck, D. Cookmeyer, H. Ö. Özturk, \& M. Wayne (Eds.), Women, science, and technology: A reader in feminist science studies (3rd ed.), (pp. 265-271). New York:

Routledge.

International Society of Genetic Genealogy. (2018 February 2). List of DNA testing companies. Retrieved from https://isogg.org/wiki/List_of_DNA_testing_companies.

Isajiw, W. W. (1993). Definition and dimensions of ethnicity: A theoretical framework. Challenges of Measuring an Ethnic World: Science, politics and reality: Proceedings of the Joint Canada-United States Conference on the Measurement of Ethnicity April 1-3, 1992 (pp. 407-427). Washington, D.C.: Statistics Canada and U.S. Bureau of the Census.

James, A. (2008). Making sense of race and racial classification. In T. Zuberi \& E. Bonilla-Silva (Eds.), White logic, white methods: Racism and methodology (pp. 31-45). Maryland: Rowman \& Littlefield Publishers Inc.

John, N. A. (2012). Sharing and web 2.0: The emergence of a keyword. New Media \& Society, 15(2), 167-182. doi: 10.1177/1461444812450684

Kayser, M., \& de Knijff, P. (2011). Improving human forensics through advances in genetics, genomics and molecular biology. Nature Reviews | Genetics, 12(3), 179-192. doi: $10.1038 / \mathrm{nrg} 2952$ 
Kapsalis, T. (2002). Mastering the female pelvis: Race and the tools of reproduction. In K. Wallace-Sanders (Ed.), Skin deep, spirit strong: The black female body in American culture (pp. 263-300). Michigan: University of Michigan Press.

Kavoori, A. (2015). Making sense of YouTube. Global Media Journal, 13(24), 1-25.

Kent, M. (2012). The importance of being Uros: Indigenous identity politics in the genomic age. Social Studies of Science, 43(4), 534-556. doi: 10.1177/0306312712468520

Kirkpatrick, B. E., \& Rashkin, M. D. (2017). Ancestry testing and the practice of genetic counseling. Journal of Genetic Counseling, 26(6), 6-20. doi: 10.1007/s10897-016-0014-2

Kolata, G. (2017, August 28). With a simple DNA test, family histories are rewritten. NY Times. Retrieved from https://www.nytimes.com/2017/08/28/science/dna-testsancestry.html?emc=edit_nn_20170829\&nl=morning-briefing\&nlid=76054167\&te=1.

Kolbert, E. (2018, April). There's no scientific basis for race - it's a made-up label. National Geographic. Retrieved from https://www.nationalgeographic.com/magazine/2018/04/race-genetics-science-africa/.

Lancaster, R. N. (2014). Cultural institutions do not reduce to genes. Contexts, 13(4), 17-18. doi: $10.1177 / 1536504214558210$

Lange, P. G. (2008). Publicly private and privately public: Social networking on YouTube. Journal of Computer-Mediated Communication, 13(1), 361-380. doi: 10.111/j.10836101.2007.00400.x

Lee, S. S. (2013a). American DNA: The political of potentiality in a genomic age. Current Anthropology, 54(7), 577-586. doi: 10.1086/670970

Lee, S. S. (2013b). Race, risk, and recreation in personal genomics: The limits of play. Medical Anthropology Quarterly, 27(4), 550-569. doi: 10.1111/maq.12059

Lee, S. S. (2015). The biobank as political artifact: The struggle over race in categorizing genetic difference. The ANNALS of the American Academy of Political and Social Science, 661(1), 143-159. Doi: 10.1177/0002716215591141

Lee, S. S., \& Crawley, L. (2009). Research 2.0: Social networking and direct-to-consumer (DTC) genomics. The American Journal of Bioethics, 9(6-7), 35-44. doi: $10.1080 / 15265160902874452$

Lee, S. S., Mountain, J., Koenig, B., Altman, R., Brown, M., Camarillo, A., Cavalli-Sforza, L., Cho, M., Eberhardt, J., Feldman, M., Ford, R., Greely, H., King, R., Markus, H., Satz, D., Snipp, M., Steele, C., \& Underhill, P. (2008). The ethics of characterizing difference: Guiding principles on using racial categories in human genetics. Genome Biology, 9(7), 1-4. doi: 10.1186/gb-2008-9-7-404 
Lewontin, R. C. (2006, June 7). Confusions about human races. Is race "real”? [Blog post]. Social Science Research Council. Retrieved from http://raceandgenomics.ssrc.org/Lewontin/.

Long, J. C., \& Kittles, R. A. (2003). Human genetic diversity and the nonexistence of biological races. Human Biology, 75(4), 449-471. doi: 10.1353/hub.2003.0058

Lugones, M. (1994). Purity, impurity, and separation. Signs, 19(2), 458-479.

Lugones, M. (2014). Musing: Reading the nondiasporic from within diasporas. Hypatia, 29(1), $18-22$.

Lynch, J., Bevan, J., Achter, P., Harris, T., \& Condit, C. M. (2008). A preliminary study of how multiple exposures to messages about genetics impact on lay attitudes towards racial and genetic discrimination. New Genetics and Society, 27(1), 43-56. doi: $10.1080 / 14636770701843634$

Lynch, J., \& Dubriwny, T. (2006). Drugs and double binds: Racial identification and pharmacogenomics in a system of binary race logic. Health Communication, 19(1), 6173.

Lynch, J., Parrott, A., Hopkin, R. J., \& Myers, M. (2011). Media coverage of direct-to-consumer genetic testing. Journal of Genetic Counseling, 20(5), 486-494. doi: 10.1007/s10897-0119374-9

Mama, A. (1995). Beyond the masks: Race, gender and subjectivity. London, UK: Routledge.

M'Charek, A. (2013). Beyond fact or fiction: On the materiality of race in practice. Cultural Anthropology, 28(3), 420-442.

McLaren, A. (1990). Our own master race: Eugenics in Canada, 1885-1945. Toronto: McClelland \& Stewart Inc.

McKinley, E. (2008). From object to subject: Hybrid identities of indigenous women in science. Cultural Studies of Science Education, 3(4), 959-975. Doi: 10.1007/s11422-008-9128-7

McWeeny, J. (2010). Liberating anger, embodying knowledge: A comparative study of María Lugones and Zen Master Hakuin. Hypatia, 25(2), 295-315.

Middleton, A. (2012). Communication about DTC testing: Commentary on a 'Family experience of personal genomics'. Journal of Genetic Counseling, 21, 392-398. doi: 10.1007/s10897-011-9472-8

Mittos, A., Blackburn, J., \& De Cristofaro, E. (2018). "23andMe confirms: I'm super white" -Analyzing Twitter discourse on genetic testing [Pre-print]. arXiv: 1801.09946v1 
Moray, N., Pink, K. E., Borry, P., \& Larmuseau, M. H. D. (2017). Paternity testing under the cloak of recreational genetics. European Journal of Human Genetics, 25, 768-770. doi: 10.1038/ejhg.2017.31

Nakamura, L. (2008). Digitizing race: Visual cultures of the Internet. Minneapolis, MN: University of Minnesota Press.

Nash, C. (2004). Genetic kinship. Cultural Studies, 18(1), 1-33. doi: $10.1080 / 0950238042000181593$

Nash, C. (2007). Mapping origins: Race and relatedness in population genetics and genetic genealogy. In P. Atkinson, P. Glasner, \& H. Greenslade (Eds.), New genetics, new identities (pp. 77-100). New York: Routledge.

Nayar, P. K. (2016). Autobiogenography: Genomes and life writing. Auto|Biography Studies, 117. doi: 10.1080/08989575.2016.1180032

Nayar, P. K. (2017). Genomes, or the book of life itself. Auto|Biography Studies, 32(2), 217-219. doi: 10.1080/08989575.2017.1288000

Nelson, A. (2008). Bio science: Genetic genealogy testing and the pursuit of African ancestry. Social Studies of Science, 38(5), 759-783. doi: 10.1177/0306312708091929

Nelson, A. (2013). DNA ethnicity as black social action? Cultural Anthropology, 28(3), 527-536. doi: 10.1111/cuan.12019

Nelson, A. (2014). Genetic ancestry testing as an ethnic option. Contexts, 13(4), 19-20. doi: $10.1177 / 1536504214558210$

Nelson, A. (2016). The social life of DNA: Race, reparations, and reconciliation after the genome. Boston: Beacon Press.

Nordgren, A., \& Juengst, E. T. (2009). Can genomics tell me who I am? Essentialist rhetoric in direct-to-consumer DNA testing. New Genetics and Society, 28(2), 157-172. doi: $10.1080 / 14636770902901595$

Oikkonen, V. (2013). Narrative analysis as a feminist method: The case of genetic ancestry tests. European Journal of Women's Studies, 20(3), 295-308.

Oikkonen, V. (2017). Temporality and belonging as transdisciplinary phenomena: Strategic encounters between queer theory and population genetic technologies. Catalyst: Feminist, Theory, Technoscience, 3(1), 1-25.

O’Riordan, K. (2011). Writing biodigital life: Personal genomes and digital media. Biography, 34(1), 119-131. doi: 10.1353/bio.2011.0001 
Ostergren, J. E., Gornick, M. C., Carere, D. A., Kalia, S. S., Uhlmann, W. R., Ruffin, M. T., Mountain, J. L., Green, R. C., \& Roberts, J. S. (2015). How well do customers of directto-consumer personal genomic testing services comprehend genetic test results? Findings from the impact of personal genomics study. Public Health Genomics, 18(4), 1-9. doi: $10.1159 / 000431250$

Pace, S. (2008). YouTube: An opportunity for consumer narrative analysis? Qualitative Market Research: An International Journal, 11(2), 213-226. doi: 10.1108/13522750810864459

Penchaszadeh, V. B. (2015). Ethical, legal and social issues in restoring genetic identity after forced disappearance and suppression of identity in Argentina. Journal of Community Genetics, 6(3), 207-213. doi: 10.1007/s12687-015-0219-3

Phelan, J. C., Link, B. G., \& Feldman, N. M. (2013). The genomic revolution and beliefs about essential racial differences: A backdoor to eugenics? American Sociological Review, 78(2), 167-191. doi: 10.1177/0003122413476034

Phelan, J. C., Link, B. G., Zelner, S., \& Yang, L. H. (2014). Direct-to-consumer racial admixture tests and beliefs about essential racial differences. Social Psychology Quarterly, 77(3), 296-318. doi: 10.1177/0190272514529439

Postan, E. (2016). Defining ourselves: Personal bioinformation as a tool of narrative selfconception. Bioethical Inquiry, 13, 133-151. doi: 10.1007/s11673-015-9690-0

Rachul, C., Ouellette, C., \& Caulfield, T. (2011). Tracing the use and source of racial terminology in representations of genetic research. Genetics in Medicine, 13(4), 314-319. doi: 10.1097/GIM.0b013e3181f5cf9a

Reardon, J. (2011). Human population genomics and the dilemma of difference. In S. Jasanoff (Ed.), Reframing rights: Bioconstitutionalism in the genetic age (pp. 217-238). Cambridge, MA: Massachusetts Institute of Technology.

Reardon, J., \& TallBear, K. (2012). "Your DNA is our history": Genomics, anthropology, and the construction of whiteness as property. Current Anthropology, 53(5), S233-S245. doi: $10.1086 / 662629$

Reeve, E. (2016, October 8). Alt-right trolls are arguing over genetic tests they think "prove" their whiteness. Vice News. Retrieved from https://news.vice.com/en_us/article/vbygqm/alt-right-trolls-are-getting-23andme-genetictests-to-prove-their-whiteness.

Regalado, A. (2018, February 12). 2017 was the year consumer DNA testing blew up. MIT Technology Review. Retrieved from https:/www.technologyreview.com/s/610233/2017was-the-year-consumer-dna-testing-blew-up/. 
Richards, M. (2010). Reading the runes of my genome: A personal exploration of retail genetics. New Genetics and Society, 29(3), 291-310. doi: 10.1080/14636778.2010.507486

Richardson, S. S. (2014). Sexing the X: How the X became the "female chromosome". In M. Wyer, M. Barbercheck, D. Cookmeyer, H. Ö. Özturk, \& M. Wayne (Eds.), Women, science, and technology: A reader in feminist science studies (3rd ed.), (pp. 334-350). New York: Routledge.

Risch, N., \& Lange, K. (1979). Application of a recombination model in calculating the variance of sib pair genetic identity. Annual Human Genetics, 43, 177-186.

Roelofs, M. (2016). Navigating frames of address: María Lugones on language, bodies, things, and places. Hypatia, 31(2), 370-387.

Roth, W. D., \& Ivemark, B. (2018). Genetic options: The impact of genetic ancestry testing on consumers' racial and ethnic identities. American Journal of Sociology, 124(1), 150-184.

Ruckenstein, M. (2017). Keeping data alive: Talking DTC genetic testing. Information, Communication \& Society, 20(7), 1024-1039. doi: 10.1080/1369118X.2016.1203975

Ruckenstein, M., \& Schüll, N. D. (2017). The datafication of health. Annual Review of Anthropology, 46, 261-278. doi: 10.1146/annurev-anthro-102116-041244

Ryall, E. (2008). The language of genetic technology: Metaphor and media representation. Continuum: Journal of Media \& Cultural Studies, 22(3), 363-373. doi: 10.1080/10304310701861556

Saukko, P. (2017). Shifting metaphors in direct-to-consumer genetic testing: From genes as information to genes as big data. New Genetics and Society, 36(3), 296-313.

Scully, M. (2018). Constructing masculinity through genetic legacies: Family histories, Ychromosomes, and "Viking identities". Genealogy, 2(8), 1-17. doi: 10.3390/genealogy2010008

Shifman, L. (2011). An anatomy of a YouTube meme. New Media \& Society, 14(2), 187-203. doi: $10.1177 / 1461444811412160$

Smart, A., Bolnick, D. A., \& Tutton, R. (2017). Health and genetic ancestry testing: Time to bridge the gap. BMC Medical Genomics, 10(3), 1-9. doi: 10.1186/s12920-016-0240-3

Smith, D. (2014). Charlie is so 'English'-like: Nationality and the branded celebrity persona in the age of YouTube. Celebrity Studies, 5(3): 256-274.

Strangelove, M. (2010). Watching YouTube: Extraordinary videos by ordinary people. Toronto: University of Toronto Press. 
Strong, K. A., May, T., McCauley, M., Kirschner, A. L. P., Jeruzal, J., \& Wilson, S. L. (2017). Adult adoptees' attitudes regarding the potential use of genetic information to fill the gap in their family health history. Adoption \& Fostering, 41(2), 159-169. Doi: $10.1177 / 0308575917704553$

Sturm, C. (2010). Becoming Indian: The struggle over Cherokee identity in the twenty-first century. Santa Fe, NM: School for Advanced Research Press.

Sturm, A. C., \& Manickam, K. (2012). Direct-to-consumer personal genomic testing: A case study and practical recommendations for "genomic counseling." Journal of Genetic Counseling, 21(3), 402-412. doi: 10.1007/s10897-012-9489-7

Sunde, K. (2015). "Welcome to you": A reflection on genetic self-exploration. Narrative Inquiry in Bioethics, 5(3), 220-222.

TallBear, K. (2013). Native American DNA: Tribal belonging and the false promise of genetic science. Minneapolis, MN: University of Minnesota Press.

Templeton, A. R. (1999). Human races: A genetic and evolutionary perspective. American Anthropologist, 100(3), 632-650.

Visscher, P. M., Medland, S. E., Ferreira, M. A. R., Morley, K. I., Zhu, G., Cornes, B. K., Montgomery, G. W., \& Martin, N. G. (2006). Assumption-free estimation of heritability from genome-wide identity-by-descent sharing between full siblings. PLoS Genetics, 2(3), 316-325. doi: 10.1371/journal.pgen.0020041

Vonderau, P. (2016). The video bubble: Multichannel networks and the transformation of YouTube. Convergence: The International Journal of Research into New Media Technologies, 22(4), 361-375. doi: 10.1177/1354856516641882

Wagner, J. K. (2010). Interpreting the implications of DNA ancestry tests. Perspectives in Biology and Medicine, 53(2), 231-248.

Wald, P. (2006). Blood and stories: How genomics is rewriting race, medicine and human history. Patterns of Prejudice, 40(4-5), 303-333. doi: 10.1080/00313220601020064

Whiton, D. N. (1997). The perceived barriers to smoking cessation that exist for women (Doctoral dissertation). Retrieved from UMI Dissertation Publishing and ProQuest Dissertations Publishing. (\#1387514).

Widdows, H. (2007). Conceptualising the self in the genetic era. Health Care Analysis, 15(1), 512. doi: 10.1007/s10728-006-0033-5

Widdows, H. (2009). Between the individual and the community: The impact of genetics on ethical models. New Genetics and Society, 28(2), 173-188. doi:

10.1080/14636770902901611 
Williams, M. (2017, May 25). The lucrative rise of DNA testing: 'We created the market for what we do'. The Guardian. Retrieved from https://www.theguardian.com/smallbusiness-network/2017/may/25/dna-testing-we-created-the-market-for-what-we-doliving-dna-dnafit-geneu.

Worrall, S. (2017, October 14). Why race is not a thing, according to genetics. National Geographic. Retrieved from https://news.nationalgeographic.com/2017/10/geneticshistory-race-neanderthal-rutherford/.

Yong, E. (2017, June 27). How African Americans use DNA testing to connect with their past. The Atlantic. Retrieved from https://www.theatlantic.com/science/archive/2017/06/howafrican-americans-use-dna-testing-to-connect-with-their-past/531834/.

YouTube. (2018). About YouTube. Retrieved from https://www.youtube.com/yt/about/.

YouTube Red. (2018). YouTube Red. Retrieved from https://www.youtube.com/red/.

Yudell, M., Roberts, D., DeSalle, R., \& Tishkoff, S. (2016). Taking race out of human genetics: Engaging a century-long debate about the role of race in science. Science, 351(6273), 564-565. doi: 10.1126/science.aac4951

Zack, N. (1993). Race and mixed race. Philadelphia: Temple University.

Zack, N. (2010). The fluid symbol of mixed race. Hypatia, 25(4), 875-890. doi: 10.1111/j.15272001-2010-01121.x

Zeiler, K. (2009). Symposium on genetics, identity and ethics. New Genetics and Society, 28(2), 153-156. doi: 10.1080/14636770902901561

Zhang, S. (2016, December 29). Will the Alt-Right promote a new kind of racist genetics? The Atlantic. https://www.theatlantic.com/science/archive/2016/12/genetics-race-ancestrytests/510962/.

Zhang, S. (2017, August 17). When white nationalists get DNA tests that reveal African ancestry. The Atlantic. Retrieved from https://www.theatlantic.com/science/archive/2017/08/white-nationalists-dnaancestry/537108/.

Zinn, M.B., \& Dill, B.T. (1996). Theorizing difference from multiracial feminism. Feminist Studies, 22(2), 321-331.

Zuberi, T., Patterson, E. J., \& Stewart, Q. T. (2015). Race, methodology, and social construction in the genomic era. The ANNALS of the American Academy of Political and Social Science, 661(1), 109-127. Doi: 10.1177/0002716215589718 
Zwart, H. (2009). The adoration of a map: Reflections on a genome metaphor. Genomics, Society and Policy, 5(3), 29-43. 